NBER WORKING PAPER SERIES

\title{
IS THE EITC EQUIVALENT TO AN NIT? CONDITIONAL CASH TRANSFERS AND TAX INCIDENCE
}

\author{
Jesse Rothstein \\ Working Paper 14966 \\ http://www.nber.org/papers/w14966
}

\author{
NATIONAL BUREAU OF ECONOMIC RESEARCH \\ 1050 Massachusetts Avenue \\ Cambridge, MA 02138
}

May 2009

Other versions of this paper are titled "Is the EITC as Good as an NIT?" I am grateful to David Card, Nada Eissa, Hank Farber, Jonah Gelbach, Hilary Hoynes, and Austin Nichols for helpful discussions, and the Princeton Industrial Relations Section and Center for Economic Policy Studies for financial support. The views expressed herein are those of the author(s) and do not necessarily reflect the views of the National Bureau of Economic Research.

NBER working papers are circulated for discussion and comment purposes. They have not been peerreviewed or been subject to the review by the NBER Board of Directors that accompanies official NBER publications.

(C) 2009 by Jesse Rothstein. All rights reserved. Short sections of text, not to exceed two paragraphs, may be quoted without explicit permission provided that full credit, including $\odot$ notice, is given to the source. 
Is the EITC Equivalent to an NIT? Conditional Cash Transfers and Tax Incidence

Jesse Rothstein

NBER Working Paper No. 14966

May 2009

JEL No. H22,H23,I38,J23

\begin{abstract}
The Earned Income Tax Credit (EITC) is intended to encourage work. But EITC-induced increases in labor supply may drive wages down, shifting the intended transfer toward employers. I simulate the economic incidence of the EITC under a range of plausible supply and demand elasticities. In all of the scenarios that I consider, a substantial portion of the intended transfer to low income single mothers is captured by employers through reduced wages. The transfer to employers is borne in part by low skill workers who are not themselves eligible for the EITC and are therefore made strictly worse off by its existence. I contrast the EITC with a traditional Negative Income Tax (NIT). The NIT discourages work, and so induces large transfers from employers of low skill labor to their workers. With my preferred parameters the EITC increases after-tax incomes by $\$ 0.73$ per dollar spent, while the NIT yields $\$ 1.39$.
\end{abstract}

\author{
Jesse Rothstein \\ Woodrow Wilson School of Public and International \\ and Department of Economics \\ Princeton University \\ Industrial Relations Section \\ Firestone Library \\ Princeton, NJ 08544 \\ and NBER \\ jrothst@princeton.edu
}




\section{Introduction}

Most means-tested transfer programs impose high effective tax rates on earned income. In recent decades, however, there has been a trend toward the imposition of labor supply conditions for the receipt of benefits. In the United States, traditional welfare was replaced with Temporary Assistance to Needy Families (TANF), which comes with time limits and work requirements, and the Earned Income Tax Credit (EITC) was repeatedly expanded. By 2000, spending on the EITC was 70\% larger than that on TANF (Hotz and Scholz, 2003).

The EITC is often seen as an implementation of a Negative Income Tax, or NIT, but its central feature distinguishes it. Where non-workers receive the largest payments under the NIT, only families with earned income can receive the EITC. This feature ensures that the EITC encourages rather than discourages labor force participation among eligible individuals. ${ }^{1}$

Saez (2002) argues that the optimal income transfer program will resemble the EITC if labor supply decisions are made primarily on the extensive (participation) margin, whereas intensive (hours) responses lead to an optimal tax that more closely resembles the NIT. Given mounting evidence that labor market participation is far more elastic with respect to the wage than are hours among participants, Saez's analysis supports the view (also advanced by Triest, 1994; Liebman, 2002; Eissa et al., 2008; and Blundell and Shephard, 2008) that the shape of the EITC schedule is a desirable one.

But Saez's analysis, like nearly all optimal tax analyses and discussions of the EITC, presumes that the incidence of taxes is entirely on workers. As Fullerton and Metcalf (2002) note, "this assumption has never been tested" (p. 29). ${ }^{2}$ A basic result in the economics of taxation is that the economic incidence of taxes depends on the elasticities of supply and demand for the good being taxed and not on their statutory incidence. If demand is less than perfectly elastic, supply-side taxes are partially passed through to the demand side via changes in the equilibrium price. Effects on prices are are of the opposite sign as those on supply, so any program that increases labor supply will lead to reduced pre-tax wages. This implies that employers of lowskill labor capture a portion of the intended EITC transfer. Moreover, because EITC recipients (primarily single mothers) compete in the same labor markets as others who are ineligible for the credit, wage declines extend to many workers who do not receive offsetting EITC payments. These unintended transfers limit the EITC's value as a tool for income redistribution. Recog-

\footnotetext{
${ }^{1}$ This is clearly true only for unmarried recipients. I discuss the incentives faced by married couples, as well as intensive margin incentives, below.

${ }^{2}$ Anderson and Meyer (1997, 2000); Bingley and Lanot (2002); Gruber (1994, 1997), and Kubik (2004) estimate tax incidence, generally finding that workers bear much but not all of the burden. Lise et al.'s (2004) examination of the Canadian Self Sufficiency Project is the only evaluation of an income transfer program of which I am aware that considers general equilibrium effects. In that study, the sign of the net benefit of the program depends on whether general equilibrium effects are allowed.
} 
nizing the endogeneity of wages thus reduces the attractiveness of work-encouraging transfers like the EITC. But the practical importance of incidence effects is unclear.

In this paper, I show that incidence effects are extremely important to the evaluation of the EITC. With plausible labor supply and demand elasticities, the unintended consequences of the EITC operating through the pre-tax wage are large relative to the direct, intended transfers. Neglecting these wage effects leads to quite misleading assessments of the impact of a hypothetical EITC expansion on labor supply, incomes, and welfare.

I begin by extending the standard partial equilibrium tax incidence model to take account of important complexities in the labor market: Tax schedules are non-linear and heterogeneous across workers; labor is differentiated and imperfectly substitutable; and supply choices combine discrete (participate or not?) and continuous (how many hours to work?) decisions. I show that targeted work subsidies produce unintended transfers to employers, coming not just from targeted workers but also from ineligible workers in the same labor markets. The transfer to employers is largest when the subsidy induces large increases in labor supply and when demand is inelastic; it is paid primarily by targeted workers only when targeted and ineligible workers are poor substitutes in production.

I derive formulas for tax incidence that depend on the labor supply elasticity measures that are commonly obtained in empirical work: the elasticity of labor force participation with respect to the average tax rate on workers' earnings and the (uncompensated) elasticity of hours worked, conditional on participation, with respect to the marginal tax rate. Although both average and marginal tax rates vary substantially across even similarly-skilled workers, I show that incidence calculations can proceed based on aggregate data with only the mean rates within appropriatelydefined cells.

To evaluate the importance of incidence considerations, I contrast two alternative income transfer policies: a small EITC expansion and a comparably-sized NIT, both targeted at families with children. Using data from the 1993 March Current Population Survey - describing the labor market immediately before a large EITC expansion in the mid-1990s - I simulate the impact on the female labor market of adding each program to the actual 1992 tax schedule. I examine effects on labor supply, earnings, and net transfers, both for all women and for women disaggregated by EITC eligibility (i.e., the presence of children), marital status, and skill.

I treat elasticities and other parameters as known. ${ }^{3}$ While I consider a range of plausible values, I focus on cases in which labor supply is more elastic at the extensive margin than at the intensive margin. In this case, with fixed wages the EITC causes net increases in low-skilled

\footnotetext{
${ }^{3} \mathrm{~A}$ companion paper (Rothstein, 2008) uses the actual mid-1990s EITC expansion to estimate the elasticities of labor supply and demand that are needed for incidence calculations. The results of that paper inform the choice of elasticity values here.
} 
women's labor supply, while the NIT reduces supply. Thus, Saez (2002) concludes that the optimal schedule resembles the EITC.

Most discussions of the elasticity implicitly assume that labor demand is infinitely elastic. The EITC induces women to supply more labor, and therefore yields increase in incomes over and above the direct tax transfer. In my baseline simulation, I estimate that low-skill mothers' incomes would rise by $\$ 1.39$ for every dollar spent on the program. When I allow for a finite demand elasticity, however, I find that the EITC produces sizable reductions in equilibrium wages that offset many of its benefits to low-skill workers. With my preferred parameters, the net-oftax incomes of women with children rise by only $\$ 1.07$ for each dollar spent on the program. Moreover, this is accompanied by a decline of $\$ 0.34$ in the net-of-tax incomes of women without children, which are pushed downward both by falling wages and by reduced labor supply. The contrast with the NIT is dramatic. The NIT imposes positive tax rates on earnings, leading to net reductions in labor supply among eligible women and thereby to increased wages. A dollar of government expenditure on the NIT produces a $\$ 0.97$ increase in the after-tax incomes of women with children and an increase of $\$ 0.42$ for women without children.

After-tax incomes are a misleading guide to the relative welfare consequences of the EITC and NIT, as much of the change in incomes is offset by changes in the consumption of leisure. ${ }^{4}$ Again using my preferred parameters, a dollar of EITC spending produces net increases in the welfare of women with children with cash value of only $\$ 0.83$ (as compared with $\$ 1$ when demand is perfectly elastic). Employers of low-skill labor capture $\$ 0.36$ via reduced wage bills, while the welfare of (EITC-ineligible) childless women falls by the equivalent of $\$ 0.18$. Moreover, this obscures the even worse welfare consequences for single mothers, the primary group targeted by the EITC. Fully 55\% of the marginal EITC dollar given to this group is captured by employers through reduced wages, and single childless women lose almost exactly as much as single mothers gain. Again, the NIT offers a dramatic contrast: The welfare of women with children rises by the equivalent of $\$ 1.32$ and that of women without children by $\$ 0.23$, with transfers of $\$ 0.55$ from employers to their workers magnifying the direct transfer from the government.

There are several limitations to my analysis. First, I ignore the taxes that would be needed to finance the proposed EITC and NIT programs. These would presumably be levied on higherincome taxpayers, though their incidence too is unclear. Second, I examine only the first-order effects of tax policy on wages, not second- and third-order effects on other prices. The analysis is thus not fully general equilibrium. Third, I neglect many of the complexities introduced by

\footnotetext{
${ }^{4}$ In general, the effects of work-encouraging (respectively, work-discouraging) programs on incomes will exceed (fall short of) the effects on welfare, as the income measure does not account for the disutility of work. However, in the words of Besley and Coate (1995), "[t]here is little evidence that the poor's leisure is valued by policy makers.” See also Besley and Coate (1992) and Moffitt (2006).
} 
nonlinear income tax schedules. I implicitly assume that small tax changes will not lead workers to jump from one segment of the tax schedule to another. This is unrealistic, but is necessary to obtain simple expressions for incidence effects and is unlikely to substantially affect the results. Finally, I do not extend the analysis to derive the implications for the optimal tax schedule. At a minimum, however, my simulation results suggest caution in deriving policy conclusions from models with fixed wages. Allowing for plausible labor demand elasticities leads to substantial changes in the distribution of outcomes.

The paper proceeds as follows. In Section 2, I develop the theoretical framework. The EITC program is described in Section 3. I also review there the evidence on the EITC's labor supply effects. Section 4 describes the data and tax simulation. Section 5 introduces the EITC and NIT policy alternatives. Section 6 describes the details of the simulation. Section 7 presents results. Section 8 concludes.

\section{A Model of Tax Incidence}

In this section, I develop a model of partial equilibrium tax incidence that is suitable to the complexities of the labor market. I begin with a simple textbook presentation, then gradually extend it to allow for heterogeneity across workers, non-proportional taxes, and distinct participation and hours choices.

\subsection{The Textbook Model}

I begin with constant-elasticity supply and demand functions for a homogenous good, with proportional taxes levied on the supplier:

$$
L^{S}(w)=\alpha(w(1-\tau))^{\sigma} \text { and } L^{D}(w)=\beta w^{\rho} .
$$

Here, $w$ is the price faced by the demander, $w(1-\tau)$ is the net-of-tax price received by the supplier, and $\sigma>0$ and $\rho<0$ are the price elasticities of supply and demand, respectively. The equilibrium pre-tax price and quantity are

$$
w=\alpha^{\frac{-1}{\sigma-\rho}} \beta^{\frac{1}{\sigma-\rho}}(1-\tau)^{\frac{-\sigma}{\sigma-\rho}} \text { and } L=\alpha^{\frac{-\rho}{\sigma-\rho}} \beta^{\frac{\sigma}{\sigma-\rho}}(1-\tau)^{\frac{-\sigma \rho}{\sigma-\rho}} .
$$

Thus, the demand side (in the market for labor, employers) bears a share $\frac{\sigma}{\sigma-\rho}$ of taxes $-d \ln w=$ $\frac{-\sigma}{\sigma-\rho} d \ln (1-\tau) \approx \frac{\sigma}{\sigma-\rho} d \tau$-and the supply side bears the remaining $\frac{-\rho}{\sigma-\rho}$ share. The demandside share represents a transfer to suppliers. The net transfer from the supply side is thus $\operatorname{Lwd} \tau\left(\frac{-\rho}{\sigma-\rho}\right)$. It is smaller in magnitude than the statutory tax whenever supply is at all elastic 
$(\sigma>0)$ and demand is less than perfectly elastic $(\rho>-\infty)$; it is smallest when supply is highly elastic and demand highly inelastic.

\subsection{Incidence with heterogeneous workers}

Workers of different skills are not perfectly substitutable in production, and even workers of the same skill may face different tax rates. The textbook model can be extended to allow for distinct labor markets and for tax rates that differ both across and within markets. For the moment, I maintain the assumptions of proportional taxes and a single labor supply elasticity. The supply of individual $i$ working in market $s$ is

$$
L_{i s}=\alpha_{i}\left(w_{s}\left(1-\tau_{i s}\right)\right)^{\sigma}
$$

This expression allows tax rates to vary freely across individuals, but assumes that the pre-tax wage is constant across workers in the same market. The total labor supplied to market $s$ is $L_{s}=\sum_{i} L_{i s}$, with differential

$$
d \ln L_{s} \equiv \frac{d L_{s}}{L_{s}}=\frac{1}{L_{s}} \sum_{i} d L_{i s}=\frac{1}{L_{s}} \sum_{i} L_{i s} d \ln L_{i s}
$$

Using (3) and again approximating $d \ln \left(1-\tau_{i s}\right) \approx-d \tau_{i s}$, this yields

$$
d \ln L_{s} \approx \sigma\left(d \ln w_{s}-L_{s}^{-1} \sum_{i} L_{i s} d \tau_{i s}\right)=\sigma\left(d \ln w_{s}-d \tau_{s}\right)
$$

where $d \tau_{s} \equiv L_{s}^{-1} \sum_{i} L_{i s} d \tau_{i s}$. Thus, aggregate labor supply to market $s$ depends on the wage in that market and on the weighted mean tax rate in the market, using individuals' baseline labor supplies as weights.

Next, I need to model the determination of wages. I assume that workers within each market are perfect substitutes and that total effective labor supply is a Constant Elasticity of Substitution (CES) aggregate of supply in each market:

$$
L=\left(\sum_{s} \beta_{s} L_{s}^{\frac{1+\rho}{\rho}}\right)^{\frac{\rho}{1+\rho}}
$$

Here, $\rho$ is the elasticity of substitution between different types of labor. Cost minimization implies a set of labor demand functions of the form:

$$
L_{s}=\psi \beta_{s}^{-\rho} w_{s}^{\rho}
$$


where $\psi=\psi\left(w_{1}, w_{2}, \ldots, w_{S}\right)$ is a parameter reflecting the aggregate demand for labor. Note that $w_{t}$ enters the expression for $L_{s}, s \neq t$, only through $\psi$. Because I focus on partial equilibrium incidence and not on changes in the price level, I neglect effects of taxes operating through $\psi$. I also assume that the $\beta_{s}$ parameters are invariant.

Differentiating the inverse demand implied by (7) yields

$$
d \ln w_{s}=\rho^{-1} d \ln \psi+\rho^{-1} d \ln L_{s}
$$

Combining (5) and (8), we obtain the quasi-reduced form

$$
\begin{aligned}
d \ln w_{s} & \approx \frac{1}{\sigma+\rho} d \ln \psi+\frac{\sigma}{\sigma-\rho} d \tau_{s} \\
d \ln L_{s} & \approx \frac{\sigma}{\sigma+\rho} d \ln \psi+\frac{\rho \sigma}{\sigma-\rho} d \tau_{s}
\end{aligned}
$$

As the mean tax rate in the labor market rises $\left(d \tau_{s}>0\right)$, relative supply of type-s labor falls (by $\frac{\rho \sigma}{\sigma-\rho} d \tau_{s}<0$ ) and relative pre-tax wages increase (by $\frac{\sigma}{\sigma-\rho} d \tau_{s}>0$ ). Just as in the textbook model, the employer's share of the change in average taxes is $\frac{\sigma}{\sigma-\rho}$.

\subsection{Implications for Subgroup Analyses}

It can also be of interest to examine the distribution of impacts across defined subgroups within market $s$. Let $d \tau_{s g} \equiv\left(\sum_{i \in g} L_{i s g}\right)^{-1} \sum_{i \in g} L_{i s g} d \tau_{i s g}$ be the supply-weighted mean tax change for subgroup $g$ in market $s$. The impact on subgroup $g$ 's net labor supply is:

$$
d \ln L_{s g} \approx \frac{\sigma}{\sigma-\rho} d \ln \psi+\frac{\sigma^{2}}{\sigma-\rho} d \tau_{s}-\sigma d \tau_{s g}
$$

Thus, labor supply of subgroup $g$ is declining in the mean tax rate in that subgroup (because $\left.\partial \ln L_{s g} / \partial \tau_{s g}=-\sigma<0\right)$ but, conditional on this, increasing in the mean across the entire labor market (because $\partial \ln L_{s g} / \partial \tau_{s}=\frac{\sigma^{2}}{\sigma-\rho}>0$ ).

Studies of the effects of tax reforms on labor supply frequently exploit contrasts between workers who plausibly participate in the same labor markets but are differently affected by a change in the tax regime (see, e.g., Eissa, 1995; Eissa and Hoynes, 2006b, 2004; Eissa and Liebman, 1996; Meyer and Rosenbaum, 2001). These can identify the supply elasticity without accounting for wage effects. To see this, simply difference (10) between subgroups $g_{1}$ and $g_{2}$ :

$$
d \ln L_{s g_{1}}-d \ln L_{s g_{2}}=-\sigma\left(d \tau_{s g_{1}}-d \tau_{s g_{2}}\right) .
$$

Frequently, group $g_{2}$ is not directly affected by the tax change (i.e. $d \tau_{s g_{2}}=0$ ). For example, 
in studies of the EITC's effect on labor supply, women without children - who are not eligible for the EITC - are often used as a "control" group. This terminology makes it seem as if the effect on the "treatment" group's labor supply is $-\sigma d \tau_{s g_{1}}$. This would be correct if wages were fixed. But with general equilibrium effects this can be quite misleading (Heckman, 1996). By (10), the net effect on group $g_{1}$ 's labor supply (neglecting changes in the price level) is

$$
d \ln L_{s g_{1}}=\left(\frac{\sigma}{\sigma-\rho} \frac{L_{s g_{1}}}{L_{s}}-1\right) \sigma d \tau_{s g_{1}} .
$$

This can be quite different from the partial equilibrium labor supply effect if the taxed group is a large share of labor market $s$. Moreover, the "control" group $g_{2}$ 's supply changes as well, by $\frac{\sigma^{2}}{\sigma-\rho} \frac{L_{s g_{1}}}{L_{s}} d \tau_{s g_{1}}$. By (9a), if $d \tau_{s g_{1}}>0(<0)$ both groups will see rising (declining) wages.

Now imagine varying groups' shares of the labor market, $L_{s g_{1}} / L_{s}$, holding $d \tau_{s}=\left(L_{s g_{1}} / L_{s}\right) d \tau_{s g_{1}}$ constant. That is, we compare a large tax cut targeted to a small group with a smaller cut spread across a larger group. The effects on employers and on group $g_{2}$ 's labor supply will be the same in either case, but the distribution of transfers will not. If group $g_{1}$ comprises the full labor market (i.e., $L_{s g_{1}}=L_{s}$ ), the full transfer to/from employers comes from this group, whose wages fall by $\frac{\sigma}{\sigma-\rho} d \tau_{s g_{1}}$. As the targeted group's share of the skill-s labor market falls, however, group $g_{2}$ bears an increasing share of the transfer to employers.

\subsection{Nonlinear tax schedules}

Finally, I extend the model to a nonlinear tax schedule. Let the tax paid by individual $i$, be an arbitrary function of individual earnings $y_{i} \equiv L_{i} w_{i}$, non-labor income $R_{i}$ (assumed to be exogenous), and demographic characteristics $X_{i}: T_{i}=T\left(y_{i}, R_{i}, X_{i}\right)$. The individual's labor supply decision will depend on the marginal tax rate on earnings, $M T R_{i} \equiv \partial T / \partial y_{i}$, and, potentially, on other aspects of the tax schedule. For example, a discrete choice between working zero hours, which provides after-tax income $R_{i}-T\left(0, R_{i}, X_{i}\right)$, and working $h>0$ hours for after-tax income $R_{i}+h w_{i}-T\left(h w_{i}, R_{i}, X_{i}\right)$ presumably depends on the average tax rate over the 0 to $h$ range, $A T R_{i} \equiv\left(h w_{i}\right)^{-1}\left[T\left(h w_{i}, R_{i}, X_{i}\right)-T\left(0, R_{i}, X_{i}\right)\right]$.

It is straightforward to extend the incidence model to the nonlinear tax case so long as $d \ln L_{s g}$ is linear in $d \ln w_{s}$ and a set of tax parameters $\left\{d \tau_{s g 1}, \ldots, d \tau_{s g k}\right\} \cdot{ }^{5}$ Assume

$$
d \ln L_{s g}=\sigma_{w} d \ln w_{s}-\sigma_{1} d \tau_{s g 1}-\cdots-\sigma_{k} d \tau_{s g k}
$$

\footnotetext{
${ }^{5}$ This is a non-trivial assumption, as in many cases (e.g. piecewise linear tax schedules) standard utility functions will not yield labor supply functions of this form. Equation (11) is perhaps best seen as a first-order linear approximation to the true nonlinear labor supply function.
} 
and labor demand as in (7). By (8), the impact of a tax shock on wages is proportional to the partial effect of the shock on labor supply, holding wages constant:

$$
d \ln w_{s}=\frac{1}{\sigma_{w}+\rho} d \ln \psi+\frac{1}{\sigma_{w}+\rho} d \ln \beta_{s}+\frac{\sigma_{1}}{\sigma_{w}+\rho} d \tau_{s 1}+\cdots+\frac{\sigma_{k}}{\sigma_{w}+\rho} d \tau_{s k} .
$$

As before, the tax rates in (11) and (12) are the hours-weighted averages across workers in market $s$.

Empirical researchers often estimate the effects of changes in average and marginal tax rates on labor force participation and on average hours among participants, respectively. The current framework can be used to incorporate these extensive and intensive responses. I neglect income effects here; the system is extended to include them in the appendix. Let $p_{s g}$ be the participation rate of group $g$ in market $s$ and let $h_{s g}$ represent average hours among participants. Total labor supply in the group is therefore $L_{s g}=N_{s g} p_{s g} h_{s g}$, where $N_{s g}$ is the number of individuals in the group. Let $\sigma_{e}$ and $\sigma_{i}$ be the extensive- and intensive-margin elasticities, respectively. Letting $d M T R_{s g}$ and $d A T R_{s g}$ be the change in mean marginal and average tax rates in the subgroup (as before, weighted by hours worked), this means that $d \ln h_{s g}=\sigma_{i}\left(d \ln w_{s}-d M T R_{s g}\right)$ and

$$
\begin{aligned}
d \ln p_{s g} & =\sigma_{e} d \ln \left(h_{s g} w_{s}\left(1-A T R_{s g}\right)\right) \\
& \approx \sigma_{e}\left(1+\sigma_{i}\right) d \ln w_{s}-\sigma_{e} \sigma_{i} d M T R_{s g}-\sigma_{e} d A T R_{s g} .
\end{aligned}
$$

The overall change in labor supply in response to a tax change is thus

$$
\begin{aligned}
d \ln L_{s g} & =d \ln p_{s g}+d \ln h_{s g} \\
& =\left(\sigma_{i}+\sigma_{e}+\sigma_{i} \sigma_{e}\right) d \ln w_{s}-\sigma_{i}\left(1+\sigma_{e}\right) d M T R_{s g}-\sigma_{e} d A T R_{s g}
\end{aligned}
$$

and the reduced-form effect of the tax change on wages is

$$
d \ln w_{s}=\frac{1}{\sigma_{i}+\sigma_{e}+\sigma_{i} \sigma_{e}-\rho}\left[d \ln \psi+\left(\sigma_{i}+\sigma_{i} \sigma_{e}\right) d M T R_{s}+\sigma_{e} d A T R_{s}\right]
$$

Several aspects of these equations are of note. First, note that the product of the intensiveand extensive-margin elasticities appears in several places. This reflects the fact that any change in hourly after-tax wages leads to an intensive-margin response, and that this in turn changes the incentive to participate. Second, all of the tax rates are hours-weighted averages among workers in the cell; the implicit assumption is that the change in ATRs and MTRs faced by working women in an $s-g$ cell captures the change in the labor supply incentives faced by 
non-workers. This is questionable, but may be a tolerable approximation. Third, if $\sigma_{e}=0,(13)$ and (14) reduce to the simpler expressions in Section 2.2, using only $\sigma_{i}$ and the marginal tax rate. Similarly, if $\sigma_{i}=0$, we obtain the same expressions from Section 2.2, this time using $\sigma_{e}$ and the average tax rate. Fourth, the same simplification does not arise when only one of the tax rates is changed but both elasticities are non-zero: A change in either tax rate influences both extensive- and intensive-margin labor supply decisions via its effect on wages. Finally, wage effects of tax changes are proportional to their impacts on labor supply. As discussed below, the EITC has opposite effects on MTRs and ATRs for many women. The net impact on the wage will depend on the sum of extensive- and intensive-margin labor supply responses.

\subsection{Continuous skill distributions}

The above model assumes that each worker participates in one of $S$ distinct labor markets, and that an increase in labor supply in one of these markets has the same proportional effect on wages in every other market. In analyses of labor supply responses that do not examine wage effects, it is conventional to define labor markets by observed education and experience. This is less attractive for demand analyses: In the CES production function used here, a shock to the labor supply of young high school dropouts must have the same proportional effects on the wages of young high school graduates as on those of older college graduates.

An alternative is to treat skill as a continuous variable. Teulings (1995, 2005) develops a model of job assignments when "close" skill types are more substitutable than are those further apart in the distribution. In his model, the labor supply that determines the wage of a worker with skill $s$ (in, e.g., the inverse version of (7)) is the local average around $s$, with more weight on skill levels closer to $s$. Moreover, in any cross section there is a one-to-one mapping from wages to skills. Thus, we can continue to use the above reduced-form equations for taxes and labor supply by simply re-defining the market-level tax shock that is relevant to worker $i$ as the local average of the change in tax rates among workers with wages close to $w_{i}$ :

$$
d \tau_{s(i)} \equiv \frac{\sum_{j} L_{j} K\left(\omega^{-1} d\left(w_{i}, w_{j}\right)\right) d \tau_{j}}{\sum_{j} L_{j} K\left(\omega^{-1} d\left(w_{i}, w_{j}\right)\right)}
$$

Here, $d\left(w_{0}, w_{1}\right)$ representes the distance from $w_{0}$ to $w_{1}$ in some metric, $K()$ is a kernel function, and $\omega$ is a bandwidth. ${ }^{6}$ As before, this local average is weighted by labor supply.

My main estimates use the conventional education-experience categorization. I also present estimates from the continuous skill model - with $d\left(w_{i}, w_{j}\right) \equiv\left|\ln w_{i}-\ln w_{j}\right|$, the Epanechnikov

\footnotetext{
${ }^{6}$ This is formally identical to a Nadaraya-Watson nonparametric estimator of the mean tax rate among wage$w_{i}$ workers. In nonparametric analyses, one would allow $\omega$ to shrink toward 0 as the sample size grows. In the Teulings model, $\omega$ is an economic parameter and should not vary with the sample size.
} 
kernel, and a bandwidth of 0.1 - as a specification check. Rothstein (2008) explores this model more fully.

\section{An Overview of the EITC}

The EITC is a refundable tax credit that depends on a family's total earnings according to a foursegment schedule. Four parameters define the credit: A phase-in rate $\tau_{1}$, a maximum credit $C$, an income level $p$ at which the credit begins to phase out, and a phase-out rate $\tau_{2}$. Table 1 describes the credit and marginal tax rate for a family with earned income $y$, depending on the range in which $y$ falls. ${ }^{7}$

All four parameters vary across family types and over time. In 1992, families without children were ineligible, and families with more than one child were slightly more generously treated (higher $C, \tau_{1}$, and $\tau_{2}$ ) than families with just one. Importantly, the schedule has never depended on the number of workers in the household. ${ }^{8}$ Figure 1 displays the 1992 schedule. Eissa and Hoynes (2008) review the EITC's dramatic expansion over time. In the mid-1990s, the schedule was made dramatically more generous, primarily by increasing $C$, $\tau_{1}$, and $\tau_{2}$ (i.e., by stretching the trapezoids in Figure 1 vertically). Subsequent expansions have instead taken the form of shifting the kink points outward (i.e., by increasing $C$ and $p$, stretching the trapezoids horizontally).

Liebman (1998) and Hotz and Scholz (2003) discuss the EITC's labor supply incentives. In the phase-in range, marginal tax rates (MTRs) are negative and substitution effects should lead to increased labor supply, but income effects may partially offset this. In the plateau region, MTRs are zero and income effects are negative. In the phase-out, substitution and income effects reinforce each other, both leading to reductions in labor supply. Thus, traditional labor supply models with continuous hours choices suggest a net negative labor supply effect.

But the annual hours distribution is extremely concentrated: $74 \%$ of women who work at all in a year work at least 48 weeks, and 52\% work between 38 and 42 hours per week. ${ }^{9}$ If the participation decision is discrete, average tax rates (ATRs) on a woman's potential earnings may be more important than MTRs. The EITC produces negative ATRs for all primary earners with potential earnings below $p+C / \tau_{2}$, so should have induced increased participation from

\footnotetext{
${ }^{7}$ If Adjusted Gross Income (AGI) - typically earnings plus non-labor income - is above $p$, the credit can be less than is shown in Table 1 and if AGI is above $p+C / \tau_{2}$ the family receives no EITC.

${ }^{8}$ Since 2002, there have been different schedules for married-couple and single tax filers, though even the married-couple schedule is invariant to the distribution of earnings within the household. Before 2002, the same schedule applied to singles and married couples.

${ }^{9}$ Among single mothers who did not attend college, a group quite likely to receive the EITC, $68 \%$ work full year and 57\% full time. The source is the 1993 March Current Population Survey sample decribed below.
} 
single parents. Among secondary earners, by contrast, nearly all of the incentives are toward reduced labor supply on both the extensive and intensive margins (Eissa and Hoynes, 2004). ${ }^{10}$

The empirical literature on labor supply is huge. Hausman (1985), Pencavel (1986), Blundell and MaCurdy (1999), and Moffitt (2002) provide reviews. Three frequent findings are that men's labor supply is quite unresponsive to changes in the wage or in non-labor income; that women's labor supply is more elastic; and that low-skill workers' supply is more elastic than that of high-skill workers. As the EITC targets low-wage women, we can expect the relevant elasticities to be fairly high.

A series of recent studies use expansions of the EITC to identify supply elasticities, typically contrasting the experiences of women with and without children. These are reviewed by Eissa and Hoynes (2006a, 2008) and Hotz and Scholz (2003). Studies of single women uniformly find that the EITC expands single mothers' labor market participation, consistent with a substantial extensive margin elasticity (Eissa and Liebman, 1996; Meyer and Rosenbaum, 2001). Also consistent with this, Eissa and Hoynes (2004) find that the EITC reduces participation among married women. Hotz and Scholz (2003) summarize the evidence as indicating an elasticity of women's labor force participation with respect to net-of-tax income between 0.69 and 1.16.

Another clear result is that effects on hours worked conditional on participation are comparatively small. Eissa and Hoynes (2006b) find an intensive-margin wage elasticity for low skill married women of 0.07 in one specification and 0.44 in another. These are if anything larger than those reported elsewhere (e.g., Eissa and Liebman, 1996 and Meyer and Rosenbaum, 2001). In a review, Meyer (2007) notes that the "lack of an 'hours effect' [of the EITC] is one of the more puzzling, yet robust findings in the literature." Saez (2009) finds evidence of bunching around the EITC kink points only among the self employed, again consistent with a small intensive-margin elasticity.

Combining the two margins, it is clear that the net effect of the EITC is to increase single mothers' total labor supply (Keane and Moffitt, 1998) and to reduce that of married women with children (Eissa and Hoynes, 2004). ${ }^{11}$ Effects on the latter group tend to be smaller than those on the former, and in any event there are fewer married than single EITC recipients. Thus, the net effect on total labor supply should be positive. But few studies examine the two groups in tandem.

Only a few studies have examined the wage impacts of the EITC. The contrast between women with and without children cannot identify these effects if both participate in the same labor markets. Thus, only weaker identification strategies are available. Rothstein (2008) com-

\footnotetext{
${ }^{10}$ If the husband's earnings are above $C / \tau_{1}$, the wife will face a non-negative MTR from her very first dollar of earnings. She also faces a positive ATR whenever the husband's earnings are below $p+C / \tau_{2}$ but her potential earnings would place the family's total income above $p$.

${ }^{11}$ The appendix discusses evidence regarding income effects.
} 
pares the wage trends for workers with different initial wages, who plausibly participated in distinct skill-level labor markets, surrounding a large EITC expansion. Allowing for skill biased technical change, he finds wage responses consistent with a demand elasticity of -0.3 . Leigh (forthcoming) contrasts workers in different states, under the assumption that labor markets are geographic, and also estimates $\rho=-0.3{ }^{12}$ Azmat (2006) studies the wage impacts of an analogue to the EITC in the UK, but focuses on the effect on the wages of recipients relative to those of non-recipients in the same labor markets. In the competitive model outlined above, this effect is necessarily zero. In this study, I sidestep the difficult challenge of identifying the demand elasticity. Rather, I take this as a parameter and simulate the implications for the EITC's incidence. I use $\rho=-0.3$ as a reasonable value, though I explore other values as well.

\section{Data}

I use data from the 1993 Annual Demographic Supplement to the Current Population Survey (CPS) - the March survey - to simulate EITC eligibility and to calibrate the impacts of the counterfactual policy changes discussed below. The 1993 data contain information about labor market participation and annual earnings and wages from 1992. I select this year because it immediately predates the large EITC expansion that began in the 1993 tax year, though there is no reason to expect that the simulation results below would be importantly sensitive to this choice.

I form tax filing units consisting of the family head and his or her spouse, if present. Following the EITC rules, the family's credit is based on the number of resident children under 18 or under 24 and enrolled in school. ${ }^{13}$ I compute hourly wages as the ratio of annual earnings to annual hours. I exclude families where the woman's hourly wage is above $\$ 100$ or below $\$ 2$, or where she has negative self employment income.

Using the CPS sample, I simulate the EITC for which each family would have been eligible in 1992 given its observed earnings. ${ }^{14}$ I use this to compute the marginal tax rate (MTR) that each working woman faces and the average tax rate (ATR) on her earnings. I use a "secondary earner" model, assuming that women treat their husbands' wages and earnings as exogenous to

\footnotetext{
${ }^{12}$ Leigh computes this as the ratio of reduced-form effects of the EITC on labor supply (of eligible and ineligible workers combined) and wages. Leigh also interprets his results as indicating that all (or more than all) of the EITC is shifted onto employers, however. This would imply inelastic demand $(\rho=0)$ and no reduced form effect on net labor supply of eligible women.

${ }^{13}$ In complex households, this only approximates the tax units used for EITC eligibility. For example, I assign a child in a multigenerational household to her mother, when in fact she might be claimed on her grandmother's return.

${ }^{14}$ The EITC also depends on the family's Adjusted Gross Income (AGI). I use Taxsim (Feenberg and Coutts, 1993) to compute this, given the relevant variables that are available in the CPS. All further calculations use my own EITC calculator.
} 
their own labor supply decisions. Accordingly, I calculate the ATR on a woman's earnings as the difference between the (negative of) the EITC credit due to the family with and without her earnings, as a share of those earnings. Both MTRs and ATRs incorporate only the federal EITC; I neglect payroll and income taxes as well as state-level EITCs and other transfer programs.

Table 2 presents an empirical analysis of the distribution of women with children across EITC segments. I divide women by marital status and, for married women, by whether they worked at all during the year. About $30 \%$ of single mothers do not work. Among those that do, slightly more are in the phase-out (positive MTR) region than in the phase-in (negative MTR). In the subset without high school diplomas (Column 4), the non-participation share is much higher, and a larger share are in the phase-in than in the phase-out region. Among married couples, the majority have incomes too high to receive the EITC. Those who are eligible are much more likely to be in the phase-out than in the phase-in range, even when I limit attention to families where the woman does not have a high school diploma. The final rows of the Table shows the fraction of working women for whom the EITC induces a positive or negative ATR. All single women who are eligible for the EITC face negative ATRs, but the presence of male earnings means that far more working married women face positive than negative ATRs.

The model in Section 2 indicates that the EITC's impact depends on the density of EITCaffected women in the labor markets in which they participate. Figure 2 shows the fraction of working women at each hourly wage who are eligible for a positive EITC, separately for single and married women. ${ }^{15}$ Throughout the bottom of the wage distribution, the majority of single women - and essentially all single mothers - receive the EITC. The share of married women receiving the credit is lower and drops off quickly at wages above about $\$ 5$. Note, however, that many married women who do not receive the EITC nevertheless face positive ATRs, as their families would be eligible for credits if the women did not work.

\section{Counterfactual policies}

I contrast two counterfactual policy reforms, each treated as additions to the 1992 tax schedule. The first is an infinitesimal proportional expansion of the EITC: A family whose credit was $c$ under the 1992 schedule would instead receive $c(1+\varepsilon)$, with $\varepsilon$ chosen to yield total incremental cost (over the sample described in Section 4, excluding single fathers) to the government of $\$ 1.16$

\footnotetext{
${ }^{15}$ These are computed by local linear regressions of an indicator for a positive simulated EITC on the log hourly wage, separately for married and single mothers. I use an Epanechnikov kernel and a bandwidth of 0.05. The regressions are weighted by annual hours worked; women with zero hours are excluded.

${ }^{16}$ This hypothetical expansion differs slightly from the large expansion that in fact took place between 1992 and 1996, which moved the kink points somewhat downward, was proportionately more generous to two-child families
} 
I contrast this EITC expansion with a similarly-infinitesimal Negative Income Tax (NIT). An NIT has only two parameters: A baseline credit $C^{N I T}$ and a rate $\tau^{N I T}$ at which it is taxed away. A family with earned income $y<C^{N I T} / \tau^{N I T}$ receives a credit of $C^{N I T}-y \tau^{N I T}$ and faces marginal tax rate $\tau^{N I T}$; a family with income above this point gets nothing. Importantly, families with zero labor income receive the full credit $C^{N I T}$ but are ineligible for the EITC. An NIT produces positive MTRs and increases in virtual income for all recipients. It also produces positive ATRs for all working single women, whether or not they actually receive the NIT, and for any married woman whose husband earns less than $C^{N I T} / \tau^{N I T}$. The NIT thus unambiguously reduces labor supply.

To make the two policies as comparable as possible, I limit my hypothetical NIT to families with children. I set the ratio of $C^{N I T}$ for families with one child and with two or more children to be the same as that for $C$ under the 1992 EITC, and set $\tau^{N I T}$ so that the NIT phases out entirely at the same income level as the EITC (i.e., so that $C^{N I T} / \tau^{N I T}=p+C / \tau_{2}$ ). This leaves one free parameter. I choose this to yield a total budgetary cost of $\$ 1$, just as for the EITC alternative. In my simulations, over $40 \%$ of NIT spending goes to families with zero labor income. As a consequence, the NIT has much smaller impacts on the labor market. ${ }^{17}$

Figure 3 shows the tax schedules in the two proposed policies. Figure 4 shows the change in mean tax rates that single and married mothers at each hourly wage would face under each policy, assuming that labor supply and wages were unchanged. In each case, I consider the proposed policies in isolation, and ignore the effects of other taxes (including the actual 1992 EITC) and transfers. The figure shows that the EITC expansion would reduce the ATR substantially (relative to the amount spent) for the average low-wage single mother. MTRs would fall as well at the lowest wages but would rise at wages between about $\$ 6$ and $\$ 11$. For married women, the EITC expansion would increase ATRs and MTRs a bit throughout the bottom of the wage distribution. The NIT alternative would increase MTRs and ATRs for all low-skill women, more so for those who are unmarried. But the magnitude of these changes would generally be smaller than those produced by the EITC expansion.

\section{Calibration Methods}

The equations in Section 2 provide simple expressions for changes in the relevant outcomes - participation rates, average hours among participants, and hourly wages - as functions of changes in tax rates. My simulation of the impact of the two proposed tax policies thus proceeds

than to one-child families, and added a small credit for families without children.

${ }^{17}$ An NIT that spends as much on working families as my hypothetical EITC expansion would cost $\$ 1.79$. As all of the incidence formulas in Section 2 are linear in the tax rate, the NIT results below should be multiplied by 1.79 to obtain the effects of a policy of this size. 
in three steps:

1. Specify the relevant labor markets.

2. Estimate changes in mean average and marginal tax rates within each market (and for relevant subgroups), given observed distributions of labor supply and wages.

3. Compute labor market responses, given specified elasticities of supply and demand.

I discuss each step in turn.

\subsection{Specification of labor markets}

In the model above, workers are separated into distinct labor markets. Hamermesh (1993) discusses the aggregation of workers into discrete groups for analyses of labor demand. He notes that the appropriate partition should yield cells within which workers are highly substitutable. Most of the studies of the demand for heterogeneous labor that Hamermesh (1993) reviews disaggregate workers by age, race, sex, or occupation. For the current purposes, there is little harm in over-dividing. If workers in two cells are perfectly substitutable, demand for workers in each cell will be highly elastic with respect to the wages in that cell, holding other wages constant. The employer share of the tax burden would be determined by the (less) elastic demand for workers in a super-cell that aggregates the two perfect substitutes.

Because the EITC primarily affects women, I focus exclusively on the labor market for women. I assume throughout that men and women participate in distinct labor markets. ${ }^{18}$ In my primary analyses, I subdivide the female labor market by the intersection of four education categories (less than high school, a high school diploma but no college, some college but no degree, and college graduates), five-year age intervals, and marital status. The first two are conventional skill proxies (see, e.g., Borjas, 2003). The last is motivated by Rothstein's (2008) finding of substantial divergence between the wages of similarly-skilled single and married women in the mid 1990s.

In sensitivity analyses, I consider several alternative categorizations. First, I consider markets that are segmented by geography. I define geographic markets by state and, within state, by whether the individual lives in a metropolitan area or not. I assume that each geographic market is further divided by whether workers have some college (or more) or not. Second, I use observed hourly wages as proxies for skill and assume that workers compete only with

\footnotetext{
${ }^{18}$ If this is incorrect, I will understate the size of each skill-level labor market and overstate the change in marketlevel mean tax rates. This will lead me to overstate the effect on pre-tax wage rates but to understate the size of the group affected by any wage changes. These balance out, so the employer share of the tax incidence would be unaffected. However, I will underestimate the share of the transfer to (from) employers that comes from (goes to) non-recipients of the EITC and NIT programs.
} 
other workers with similar hourly wages. This analysis uses the continuous skill distribution discussed in Section 2.5. Finally, for each labor market proxy, I explore separating or pooling the markets for single and married women.

\subsection{Simulated tax rate changes}

For each family in the CPS sample described above, I simulate eligibility for each of the proposed tax credits, using observed labor supply and wages. As discussed above, I treat married women as secondary earners in computations of average tax rates. I then average across women in the same market to obtain mean marginal and average tax rates. As discussed in Section 2, these averages are weighted by annual hours of work.

I treat all intensive margin responses as occurring along linear budget constraints that coincide with the segment of the tax schedule on which the individual is observed. Hausman (1985) emphasizes that some individuals will jump from one segment to another in response to a tax change. An example would be someone who would reduce her hours, lowering her total earnings from just above $\$ 22,370$ to just below it, in order to qualify for the proposed EITC or NIT. My strategy treats her MTR as zero, when in fact it would be positive at her new labor supply. Two defenses can be offered for my approach, which will tend to overstate labor supply responses to tax changes around convexities in the budget set (points where MTRs increase as earnings rise) and understate responses around non-convex kinks (where MTRs decline). ${ }^{19}$ First, the evidence suggests that behavioral responses to nonlinearities in the tax schedule are relatively small. Saez (2009), for example, finds no evidence of bunching around convex kinks in the tax schedule. Second, the consequences for my analysis of mis-measuring any individual's tax rate are minor. The key rates are the means within relatively large cells, and these are likely to be reasonably accurately proxied by my no-bracket-switching simulations.

\subsection{Calibration of labor market responses}

Given labor market definitions and estimates of the change in mean tax rates in each labor market and subgroup, it is straightforward to apply equations (14) and (13) to obtain the changes in labor market participation, hours conditional on participation, and wages that the two proposed transfer programs would produce. I assume that changes in participation rates will not lead to

\footnotetext{
${ }^{19}$ The alternative would be to fully model the individual labor supply choice under the counterfactual tax regimes. This would require assumptions about the full distribution of utility function parameters. However, the utility specifications that have been used in the structural labor supply literature have a difficult time explaining the common reduced-form result that extensive margin supply responses are much larger than those on the intensive margin (Meyer, 2002). Absent better understanding of this issue, it seems best to stick to a labor supply function that is consistent with the evidence, without attempting to derive this from a behavioral model.
} 
changes in the mean wage of workers in the cell through composition effects (i.e. selection), and that any composition effects on mean hours are captured by the intensive margin elasticity. ${ }^{20}$ Finally, I assume that non-labor income, family structure, and male earnings are invariant to the tax changes under consideration.

My baseline estimates assume that the elasticity of women's participation with respect to average wages is 0.75 , that the elasticity of hours with respect to marginal wages conditional on working is zero, and that the own-price elasticity of demand for labor within each market is -0.3 . Income effects are assumed to be zero, though I present specification checks that allow for them.

The supply elasticities roughly correspond to consensus estimates in the literature reviewed in Section 3. But the demand elasticity merits further discussion, as it is central to the present analysis and much less is known about it. My parameter choice corresponds to Hamermesh's $(1993$; 1995) "best guess" at the elasticity of demand for homogeneous labor; he suggests a plausible range of -0.15 and -0.75 . Although one might expect the demand for workers of particular types to be more elastic, the estimates that Hamermesh reviews do not show clear evidence of this. Moreover, Hamermesh's guess corresponds closely to the estimates discussed in Section 3 that exploit EITC expansions.

By contrast, more recent estimates indicate a much wider range of possible values. Generally, studies that exploit exogenous shifts in wages tend to find small quantity responses, consistent with inelastic demand, while those that exploit shocks to labor supply (typically from immigration) find small wage responses that indicate more elastic demand. Thus, for example, the small-to-zero employment effects of minimum wage increases found by Card and Krueger (1995) would suggest quite inelastic demand for low skill labor (i.e. $\rho$ close to zero). And in a study of worker's compensation insurance, Gruber and Krueger (1991) estimate a demand elasticity of -0.5 . By contrast, the immigration literature is divided between estimates that immigration has essentially no effect on native wages (e.g., Card, 1990), indicating $\rho=-\infty$, and those that indicate small effects consistent with own-wage labor demand elasticities around -2.5 (Borjas, 2003; Borjas and Katz, 2007). ${ }^{21}$

I have conducted extensive sensitivity analyses that vary the elasticity parameters. In the results below, I present simulations that use elasticities of participation with respect to average wages (i.e., extensive-margin elasticities) of 1, 0.75, and 0.5; elasticities of hours with respect to marginal wages (i.e. intensive-margin elasticities) of $0,0.25$, and 0.5 ; and demand elasticities

\footnotetext{
${ }^{20}$ This is consistent with most reduced-form analyses, which focus on hours conditional on participation.

${ }^{21}$ Card (2009) argues that with an appropriate definition of skill (focusing on the high school-college distinction rather than the high school dropout-diploma distinction), immigration has not led to a substantial relative increase in low-skill labor supply. This suggests that the immigration studies, which focus on the impact on relative wages of skilled and unskilled native workers, have little power for estimation of $\rho$.
} 
of $-\infty,-1,-0.3$, and 0 .

As seen in Figure 4, the EITC and NIT policies have quite different effects on the MTRs and ATRs faced by their recipients, particularly their unmarried recipients. Before jumping in to the evaluation of these policies, it is worth considering the implications of different elasticity parameters for the net impact of across-the-board increases in MTRs and ATRs. Table 3 reports the reduced-form effects of such increases on pre-tax wages and labor supply (combining employment and hours among the employed), using equations (14) and (13). The baseline values are highlighted for emphasis. Relative to these, the less elastic is demand, the smaller the net labor supply response to any tax change and the larger the wage response. Higher extensivemargin supply elasticities produce larger reductions in labor supply in response to tax increases and (for $\rho>-\infty$ ) larger increases in pre-tax wages. The effects of increasing the intensivemargin supply elasticity are more complex, as even when ATRs increase with no change in the MTR, wage responses can lead to intensive-margin increases in hours.

\section{Results}

I begin by analyzing the case of perfectly elastic demand $(\rho=-\infty)$. This extreme case helps make clear the direct labor supply effects of the two proposed tax policies, as there are no indirect effects when the labor market can absorb arbitrary supply shocks without changes in wages. Table 4 presents the simulated labor supply effects, using extensive margin supply elasticity $\sigma_{e}=0.75$ and intensive margin elasticity $\sigma_{i}=0 .{ }^{22}$ Panel A describes the proposed EITC expansion, while Panel B describes the NIT. All effects are characterized in terms of the total amount of additional (or reduced) earnings due to the addition of the small hypothetical programs. Recall that each program is calibrated so that the total tax expenditure is $\$ 1$.

The first two rows of each panel describe these tax transfers. By construction, all EITC spending goes to families with positive earnings. In my simulation, 55 cents of every dollar goes to single mothers, and 45 cents to married couples. The proposed NIT would give a notably larger share of funds to single mothers, 67 cents per dollar spent. $44 \%$ of the spending on the NIT, however, goes to families without earned income, and over three quarters of this spending goes to single mothers.

The next row presents the effects on the labor market. By construction, the only responses in this simulation are on the supply side at the extensive margin. My simulation indicates that each dollar spent on the EITC leads to an extra \$0.61 in earnings from new unmarried participants and to $\$ 0.22$ less in earnings from a net reduction in married women's participation, for a net

\footnotetext{
${ }^{22}$ Note that the definition of labor markets is irrelevant with $\rho=-\infty$, as there are no spillover effects from taxed to untaxed workers in any case.
} 
increase in earnings of $\$ 0.39$. The NIT, by contrast, causes reductions in participation of both single and married mothers. Earnings fall by a total of $\$ 0.62$. With perfectly elastic demand, there are no spillovers to women without children under either policy.

The final row of each panel shows the change in after-tax income under each of the proposed policies, combining the direct transfer with the change in earnings due to increased or reduced labor market participation. ${ }^{23}$ The labor supply effects of the EITC add to the direct transfer to single mothers, so incomes rise by $\$ 1.16$. Incomes of married-couple families rise by only $\$ 0.23$, as about half of the $\$ 0.45$ in tax payments is offset by reduced female earnings. Total after-tax incomes rise by $\$ 1.39$. Under the NIT, the change in total after-tax incomes is only $\$ 0.38$, as the majority of the money spent on the program is offset by reduced earnings.

Table 4 clearly shows the EITC to be a more cost-effective means of raising low-skilled women's incomes. This echoes the conclusions of many studies of the EITC. However, this result turns out to be entirely dependent on the assumption that labor demand is perfectly elastic and wages therefore exogenous. Table 5 presents my preferred simulations, using the same supply parameters and somewhat inelastic demand $(\rho=-0.3)$. Where Table 4 indicated that an EITC expansion would increase total earnings by $\$ 0.39$, operating entirely through labor supply responses, Table 5 indicates that total earnings would fall by $\$ 0.27$. This reflects a small net increase in labor supply $(+\$ 0.09)$ and a substantial $(-\$ 0.36)$ reduction coming from decreased pre-tax wages.

Columns 2-5 describe the distribution of effects across single mothers, single women without children, married mothers, and married women without children. Single mothers' labor supply rises by $\$ 0.35$, a bit more than half as much as it did in the no-wage-response model. Married mothers' supply falls by $\$ 0.10$. Recall that I model single and married women as participating in distinct labor markets. Thus, wages fall in the single women markets and rise in the markets for married women's labor. In each case, these wage impacts are shared between mothers (who are eligible for the EITC or NIT) and ineligible non-mothers. The wage impacts then lead to follow-on changes in labor supply among non-mothers, partially offsetting the effects on mothers' supply. Thus, while the labor supply of single mothers rises substantially relative to that of non-mothers, the absolute increase in single women's supply is fairly small.

The final rows of Panel A describe the total effects on after-tax incomes and transfers. For each dollar spent on the EITC, total after-tax incomes rise by only $\$ 0.73$. This reflects increases for single and married mothers that are slightly larger than the direct tax transfers, and substantial declines for single women without children. $\$ 0.64$ of the $\$ 0.73$ in increased total income

\footnotetext{
${ }^{23}$ With large policy shifts, there would be an interaction effect as changes in labor supply behavior lead to altered credit eligibility. Because I focus on extremely small policies and I neglect their effects on eligibility for other programs (including the actual 1992 EITC), the interactions are too small to show up in the Table and the actual tax transfer equals, within rounding error, the intended transfer.
} 
represents net changes in transfers. Beyond the direct tax transfers, there are large transfers from single women to their employers and smaller transfers from employers to married women. Both are divided between women with and without children. For single women, the transfer to employers is large enough to almost fully offset EITC payments, and welfare rises by an aggregate of less than $\$ 0.01$. But this reflects a $\$ 0.24$ increase in the welfare of single mothers and a $\$ 0.23$ reduction in the welfare of single, childless women.

Panel B repeats the exercise for the NIT. The picture looks entirely different. As in Table 4, we see that $\$ 0.44$ of every dollar spent on the NIT goes to non-working families. The availability of the benefit to non-workers leads to small reductions in labor supply (reducing earnings on net by $\$ 0.16$ ) and large increases in wages (adding $\$ 0.55$ to total earnings). Thus, the net effect is to increase after-tax income by $\$ 1.39$, and the net transfer to workers is even larger, $\$ 1.55$. Even childless women receive positive transfers and see increases in their wages and after-tax incomes.

The negative net effect of the EITC on wages in Table 5 is driven by the large increase in single women's labor supply that the EITC induces with fixed wages (as seen in Table 4). This occurs because the EITC produces negative ATRs for all low wage single mothers. As I assume that the extensive margin is reasonably elastic but that labor supply on the intensive margin where many single mothers face positive tax rates - is completely inelastic, the net effect is necessarily positive. Although these supply parameters correspond with what studies of the EITC's labor supply effects have found, it is nevertheless worth exploring the possibility of an intensive margin response.

Table 6 presents the simulation when I allow for an intensive-margin supply elasticity of 0.25. Compared with Table 5, the labor supply response to the EITC among single mothers is dampened - an increase of $\$ 0.22$ as compared with $\$ 0.35$, despite a wage decline that is only half as large. This reflects a participation response that is nearly identical to that seen in Table 5, combined with an offsetting but smaller hours response. The net effect is to leave single mothers' earnings almost unchanged. However, single childless women's earnings fall substantially: The wage effect remains non-trivial, and this has effects on both extensive and intensive margin supply decisions. When we combine married and single women, total earnings fall by $\$ 0.07$. This is driven primarily by wage responses, with approximately zero net supply effect. After-tax incomes rise by $\$ 0.93$, more than in Table 5 but still less than the fiscal cost.

Intensive margin supply responses have much less of an effect on the evaluation of the NIT (Panel B of Table 6). Here, ATRs and MTRs move in the same direction, and the labor market effects continue to produce a large multiplier for government spending. 


\subsection{Alternative Parameters and Definitions}

I have also explored a variety of alternative elasticity parameters. Figure 5 reports the net total transfer to workers for each of 36 values for the $\left(\sigma_{e}, \sigma_{i}, \rho\right)$ parameter vector. The values used in Table 5 are highlighted for reference. Each panel shows estimates corresponding to a particular demand elasticity, for all nine combinations of three extensive-margin and three intensive-margin supply elasticity parameters.

The upper left panel shows the case of perfectly elastic demand. In this case, the economic transfer necessarily equals the statutory transfer. In each of the three remaining panels, the EITC produces less than $\$ 1$ in transfers to workers whenever labor supply is inelastic on the intensive margin. The shortfall is largest the less elastic is demand. ${ }^{24}$ Figure 5 also shows corresponding simulations of the NIT. Under all 27 parameter combinations with less than perfectly elastic demand, there are large net transfers from employers to their workers, magnifying the direct effects of the tax credits. The size of these transfers is sensitive to the demand elasticity but less so to the supply parameters.

Figure 6 shows how the distribution of transfers across subgroups (married and single, with and without children) varies with the demand elasticity. I show estimates only for my preferred supply elasticities ( $\sigma_{x}=0.75$ and $\left.\sigma_{i}=0\right)$ here. The less elastic is demand, the more employers are able to capture via reduced wages to unmarried women, both with and without children, and the more they must give to married women via increased wages. In the extreme case of inelastic demand, there is approximately zero transfer to single mothers (the primary target of the EITC), a large transfer from single childless women to their employers, a transfer to married mothers that is over $50 \%$ larger than the direct tax transfer, and a small transfer to married childless women as well. Estimates for other parameter combinations are shown in Appendix Figures 1 (EITC) and 2 (NIT). One result is worthly of note: Even with a large intensive-margin supply elasticity, the transfer to single mothers is notably smaller when wages are allowed to respond than when demand is assumed to be perfectly elastic.

The estimates in Figures 5 and 6 assume that there are no income effects on labor supply. Appendix Table 1 presents estimates that allow for such effects, modifying the methodology described above in ways discussed in the Appendix text. Income effects reduce total labor supply under both programs, leading to higher wages and larger net transfers to workers. With large income elasticities, my baseline demand elasticity produces a net total transfer of $\$ 1.25$ from the EITC (as compared with $\$ 0.93$ with the same wage elasticities but no income effects) and $\$ 1.76$ from the NIT (compare to \$1.53). Thus, my omission of income effects from the

\footnotetext{
${ }^{24}$ When the intensive-margin supply elasticity is large, total transfers are generally around $\$ 1$, indicating little or no net transfer to or from employers. But this masks offsetting transfers from unmarried women to their employers and from employers to married women. See Appendix Figure 1.
} 
main estimates does not affect the assessment of the relative attractiveness of the EITC and NIT as transfer programs.

Table 7 explores the sensitivity along a different dimension, using my baseline parameters ( $\sigma_{e}=0.75, \sigma_{i}=0$, no income effects, and $\rho=-0.3$ ) but varying the partition of women into labor markets. I report the net total transfer and the change in after-tax income, both for all women and for single mothers. The first row of each panel repeats the estimates from the baseline simulation in Table 5. The second row considers the case where labor markets are defined by geography (separate metropolitan and non-metropolitan markets in each state) interacted with education (using a binary college-or-not classification). This has only small effects on the estimates, for the EITC producing better outcomes for single women and worse outcomes for married women. The third row returns to skill-based labor markets, using the continuous skill distribution discussed in Section 2.5. This makes the EITC look somewhat more attractive, primarily due to changes in married women's outcomes.

In my baseline model and in the first rows of Table 7, I assume that single and married women participate in distinct labor markets. This assumption is not theoretically motivated. In the second set of estimates in each panel of Table 7, I assume that married and single women compete for the same jobs. This has essentially no effect on the outcomes for all women, but dramatically improves the impact of the EITC on single mothers. Recall that the labor supply effects of the EITC are of opposite signs for married and single women. Thus, the merging of the two labor markets dampens the net change in labor supply and therefore the downward change in single women's wages. The NIT results are less sensitive to the assumption about labor market definitions, largely because the labor supply of single and married women responds in the same direction.

Taking the results of the various sensitivity analyses together, I conclude that the labor market impacts of the two proposed policies are moderately sensitive to reasonable variations in the labor supply parameters and much less dependent on the particular labor market definition used. They are quite insensitive to the demand elasticity within plausible ranges. The general conclusion of the earlier analysis, that the superiority of the EITC over the NIT is not robust to loosening the implicit assumption of perfectly elastic labor demand, does not appear to depend on the particular modeling choices made there.

\subsection{Distributional impacts}

Of course, neither the EITC nor the NIT is intended to transfer money to mothers as a class; both are intended as income support policies for low-wage families with children. Thus, part of the evaluation of the policies must depend on their distributional effects within demographic 
groups. Table 8 explores the distributional impact of the two proposed programs using the baseline elasticity parameters.

In Panel A, the estimates use my baseline marital status-education-age market definitions and show impacts across the four education categories. For each cell, I show the intended tax transfer under each policy and the actual transfer (including wage effects) as a share of this, separately for all women and for single mothers. The total transfer under the EITC, as seen earlier, is about two thirds of what was intended, and single mothers receive less than half of the intended transfer. Statutory transfers under each policy are heavily tilted toward women with below-average education. Under the EITC, "leakage" through reduced wages is largest for the middle education cells, while in the highest and lowest education groups a larger share of the tax transfer sticks with the intended recipients. By contrast, under the NIT all four education groups receive a follow-on transfer from employers that magnifies the tax credit. The ratio of this follow-on transfer to the original credit is increasing in education.

In Panel B, I return to the continuous skill definition, based on the hourly wage. This makes it possible to examine the effects of the two policies on each decile of the wage distribution. Both policies are targeted at the lower end of the distribution, with about $70 \%$ of the credits paid to working women ( $90 \%$ for working single women) going to those in the bottom half of the wage distribution. Under the EITC, less than two thirds of the intended transfers to low-wage women stick there, while the small tax transfers to the highest deciles (mostly going to single women with low annual hours) are accompanied by relatively large wage increases. A similar pattern appears for the NIT: Though even the lowest deciles obtain larger transfers than were intended, the magnifying effect of these follow-on transfers is much larger in the higher-wage categories. Under each policy, the upper-decile wage effects are concentrated among married women. Even relatively high-wage married women may face positive ATRs (see Figure 4), and the resulting reduction in their labor supply leads to wage increases in this submarket.

\section{Discussion}

Analyses of tax and transfer policy, both theoretical and empirical, have tended to ignore the potential effects of these policies on wage rates. The implicit assumption has been that the entire economic incidence of taxes is on workers. Although some empirical analyses (e.g., Gruber, 1997; Anderson and Meyer, 2000) find evidence in support of this, others (Anderson and Meyer, 1997; Kubik, 2004; Leigh, forthcoming) suggest that employers are likely to bear a portion of the tax burden as well.

The neglect of incidence considerations is defensible in some contexts. But when tax policy is used explicitly as a tool to manage labor supply incentives, as with the EITC, the issue 
can no longer be ignored. This paper has shown that under reasonable demand elasticities substantial portions of the funds expended on the EITC are shifted to employers, with negative consequences both for EITC recipients and for ineligible workers in the same labor markets. Although the exact magnitudes of these effects are sensitive to the details of the simulation, their qualitative importance is quite robust.

Many discussions of tax policy have concluded that the EITC resembles the optimal tax schedule or that it is a cost-effective mechanism for raising the incomes of low-skill workers with children. All of these are based on fixed-wage analyses in which the results generally turn on the substantial positive effects of the the EITC on labor supply. Allowing wages to adjust substantially weakens the case for the EITC. With reasonable parameter values the net effect of the program on the earnings of single mothers is negligible, as declines in wages offset increases in hours. Feasible alternative policies, including the NIT, are much more effective.

There are several limitations to the analysis undertaken here. In addition to those mentioned earlier, three are worth highlighting as potential directions for future work. First, I have assumed that labor supply elasticities are constant across female workers of different types. It would be straightforward to extend the formulas in Section 2 to allow for heterogeneity in labor supply behavior. Eissa and Hoynes (2004) estimate a wage elasticity of participation for married women that is much smaller than those typically obtained for single women. With uniform elasticities, the EITC's negative effect on married women's labor supply partially offsets its positive effect on that of single mothers. If in fact married women are less responsive than are single women, this offsetting effect is overstated, and the EITC's net wage effects are even more negative than those presented above.

Second, I have ignored the interaction between my proposed EITC and NIT policies and other preexisting distortions to the low-skill labor market. These would affect the welfare results: By treating my proposed policies as the only taxes I have been able to ignore deadweight losses as second-order, where in fact the EITC might yield first-order reductions in deadweight loss produced by other work-discouraging programs. Interactions between the EITC and other programs might also have first-order effects on the government budget. But my results on aftertax incomes would not be affected by the inclusion of other programs in the simulation.

Finally, it would be interesting to examine the impact of incidence effects on the design of optimal transfers. The results here indicate that labor-supply-promoting schedules are less desirable than one might otherwise expect. A plausible consequence is that the optimal tax should have higher (less negative) tax rates at low incomes. This would be a fruitful topic for future research. 


\section{References}

Anderson, Patricia M. and Bruce D. Meyer, "The Effects of Firm Specific Taxes and Government Mandates with an Application to the US Unemployment Insurance Program," Journal of Public Economics, August 1997, 65 (2), 119-145.

_ and _, "The Effects of the Unemployment Insurance Payroll Tax on Wages, Employment, Claims and Denials," Journal of Public Economics, October 2000, 78 (1-2), 81-106.

Azmat, Ghazala, "The Incidence of an Earned Income Tax Credit: Evaluating the Impact on Wages in the UK," Discussion Paper CEPDP0724, CEP 2006.

Besley, Timothy and Stephen Coate, "Workfare versus Welfare: Incentive Arguments for Work Requirements in Poverty-Alleviation Programmes," American Economic Review, March 1992, 82 (1), 249-62.

_ and _ , "The Design of Income Maintenance Programmes," Review of Economic Studies, April 1995, 62 (2), 187-221.

Bingley, Paul and Gauthier Lanot, "The Incidence of Income Tax on Wages and Labour Supply," Journal of Public Economics, February 2002, 83 (2), 173-194.

Blundell, Richard and Andrew Shephard, "Employment, Hours of Work and the Optimal Design of Earned Income Tax Credits," Working Paper W08/01, Institute for Fiscal Studies April 2008.

— and Thomas MaCurdy, "Labor Supply: A Review of Alternative Approaches," in Orley Ashenfelter and David Card, eds., Handbook of Labor Economics, Vol. 3A, Elsevier, 1999, pp. 1559-1695.

Borjas, George J., "The Labor Demand Curve is Downward Sloping: Reexamining the Impact of Immigration on the Labor Market," Quarterly Journal of Economics, 2003, 118 (4), 13351374.

- and Lawrence F. Katz, "The Evolution of the Mexican-Born Workforce in the United States," in George J. Borjas, ed., Mexican Immigration, University of Chicago Press, 2007, pp. 13-56.

Card, David, "The Impact of the Mariel Boatlift on the Miami Labor Market," Industrial and Labor Relations Review, January 1990, 43 (2), 245-257.

_ , "Immigration and Inequality (Ely Lecture)," in "in" American Economic Association San Francisco January 2009.

- and Alan B. Krueger, Myth and Measurement: The New Economics of the Minimum Wage, Princeton, NJ: Princeton University Press, 1995.

Eissa, Nada, "Taxation and Labor Supply of Married Women: The Tax Reform Act of 1986 as a Natural Experiment," Working Paper 5023, National Bureau of Economic Research February 1995. 
_ and Hilary W. Hoynes, "Taxes and the Labor Market Participation of Married Couples: The Earned Income Tax Credit," Journal of Public Economics, August 2004, 88 (9-10), 19311958.

_ and _ , "Behavioral Responses to Taxes: Lessons from the EITC and Labor Supply," Tax Policy and the Economy, 2006, 20, 73-110.

_ and _, "The Hours of Work Response of Married Couples: Taxes and the Earned Income Tax Credit," in Jonas Agell and Peter Birch Sorensen, eds., Tax Policy and Labor Market Performance, Cambridge and London: MIT Press, 2006, pp. 187- 227.

_ and _, "Redistribution and Tax Expenditures: The Earned Income Tax Credit," Working Paper 14307, National Bureau of Economic Research 2008.

— and Jeffrey B. Liebman, "Labor Supply Response to the Earned Income Tax Credit," Quarterly Journal of Economics, May 1996, 111 (2), 605-637.

_ , Henrik Jacobsen Kleven, and Claus Thustrup Kreiner, "Evaluation of Four Tax Reforms in the United States: Labor Supply and Welfare Effects for Single Mothers," Journal of Public Economics, April 2008, 92 (3-4), 795-816.

Feenberg, Daniel Richard and Elizabeth Coutts, "An Introduction to the TAXSIM Model," Journal of Policy Analysis and Management, 1993, 12 (1), 189-194.

Fullerton, Don and Gilbert E. Metcalf, “Tax Incidence,” in Alan J. Auerbach and Martin S. Feldstein, eds., Handbook of Public Economics, volume 4, New York: North-Holland, 2002, pp. 1787-1872.

Gruber, Jonathan, “The Incidence of Mandated Maternity Benefits," American Economic Review, 1994, 84 (3), 622-41.

_ , "The Incidence of Payroll Taxation: Evidence from Chile," Journal of Labor Economics, 1997, 15 (3, part 2), S72-S101.

— and Alan B. Krueger, "The Incidence of Mandated Employer-Provided Insurance: Lessons from Workers' Compensation Insurance," in David Bradford, ed., Tax Policy and the Economy, Vol. 5, Cambridge, MA: The MIT Press, 1991, pp. 111-144. '.

Hamermesh, Daniel S., Labor Demand, Princeton and Chichester, U.K.: Princeton University Press, 1993.

_ , "Labour Demand: Status and Prospects," in Louis N. Christofides, E. Kenneth Grant, and Robert Swidinsky, eds., Aspects of labour market behaviour: Essays in honour of John Vanderkamp, Toronto: University of Toronto Press, 1995, pp. 47-63.

Hausman, Jerry A., “Taxes and Labor Supply," in Alan Auerbach and Martin S. Feldstein, eds., Handbook of Public Economics, Vol. 1, Elsevier, 1985, pp. 213-263. 
Heckman, James J., "Comment (on 'Labor Supply and the Economic Recovery Tax Act of 1981,' by Nada Eissa),' in Martin Feldstein and James M. Poterba, eds., Empirical Foundations of Household Taxation, University of Chicago Press, 1996, pp. 32-38.

Hotz, V. Joseph and John Karl Scholz, “The Earned Income Tax Credit,” in Robert A. Moffitt, ed., Means-Tested Transfer Programs in the United States, Chicago: University of Chicago Press, 2003, pp. 141-198.

Keane, Michael and Robert Moffitt, "A Structural Model of Multiple Welfare Program Participation and Labor Supply," International Economic Review, August 1998, 39 (3), 553-589.

Kubik, Jeffrey D., "The Incidence of Personal Income Taxation: Evidence from the Tax Reform Act of 1986," Journal of Public Economics, 2004, 88 (7-8), 1567-1588.

Leigh, Andrew, "Who Benefits from the Earned Income Tax Credit? Incidence Among Recipients, Coworkers and Firms," B.E. Journal of Economic Analysis and Policy, forthcoming.

Liebman, Jeffrey B., "The Impact of the Earned Income Tax Credit on Incentives and Income Distribution," in James M. Poterba, ed., Tax Policy and the Economy, volume 12, Cambridge, MA: MIT Press, 1998, pp. 83-119.

_ , "The Optimal Design of the Earned Income Tax Credit," in Bruce D. Meyer and Douglas Holtz-Eakin, eds., Making Work Pay: The Earned Income Tax Credit and Its Impact on American Families, New York: Russell Sage Foundation Press, 2002.

Lise, Jeremy, Shannon Seitz, and Jeffrey Smith, "Equilibrium Policy Experiments and the Evaluation of Social Programs," Working Paper 10283, National Bureau of Economic Research January 2004.

Meyer, Bruce D., "Labor Supply at the Extensive and Intensive Margins: The EITC, Welfare, and Hours Worked," American Economic Review, May 2002, 92 (2), 373-379.

_ , "The U.S. Earned Income Tax Credit, its Effects, and Possible Reforms," Swedish Economic Policy Review, 2007, 14 (0720), 55-80.

- and Dan T. Rosenbaum, "Welfare, the Earned Income Tax Credit, and the Labor Supply of Single Mothers," Quarterly Journal of Economics, 2001, 116 (3), 1063-1114.

Moffitt, Robert A., "Welfare Programs and Labor Supply," in Alan J. Auerbach and Martin S. Feldstein, eds., Handbook of Public Economics, volume 4, New York: North-Holland, 2002, pp. 2394-2430.

_ , "Welfare Work Requirements with Paternalistic Government Preferences," The Economic Journal, November 2006, 116, F441-F458.

Pencavel, John, "Labor Supply of Men: A Survey," in Orley Ashenfelter and Richard Layard, eds., Handbook of Labor Economics, Vol. 1, Amsterdam: Elsevier, 1986, pp. 3-102.

Rothstein, Jesse, "The Unintended Consequences of Encouraging Work: Tax Incidence and the EITC," Unpublished manuscript, Princeton University May 2008. 
Saez, Emmanuel, "Optimal Income Transfer Programs: Intensive versus Extensive Labor Supply Responses,” Quarterly Journal of Economics, 2002, 117 (3), 1039-1073.

_ , "Do Taxpayers Bunch at Kink Points? Evidence, Elasticity Estimation, and Salience Effects," Unpublished manuscript, University of California, Berkeley April 2009.

Teulings, Coen, "The Wage Distribution in a Model of the Assignment of Skills to Jobs," Journal of Political Economy, 1995, 103 (2), 280-315.

_ , "Comparative Advantage, Relative Wages, and the Accumulation of Human Capital," Journal of Political Economy, 2005, 113 (2), 425-461.

Triest, Robert K., "The Efficiency Cost of Increased Progressivity," in Joel Slemrod, ed., Tax Progressivity and Income Inequality, Cambridge University Press, November 1994. 
Figure 1. 1992 EITC schedule

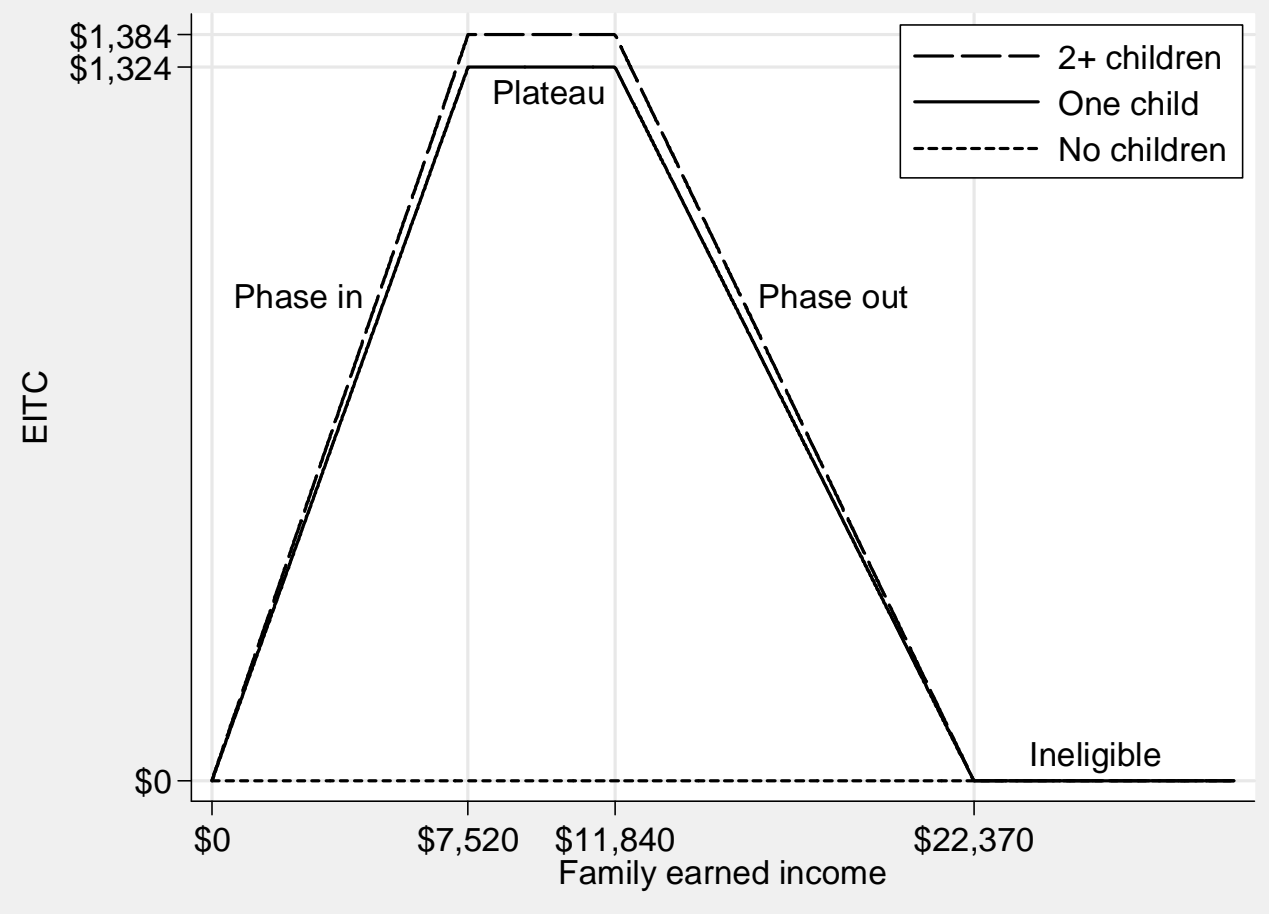

Figure 2. Fraction of working women eligible for EITC, by marital status and hourly wage

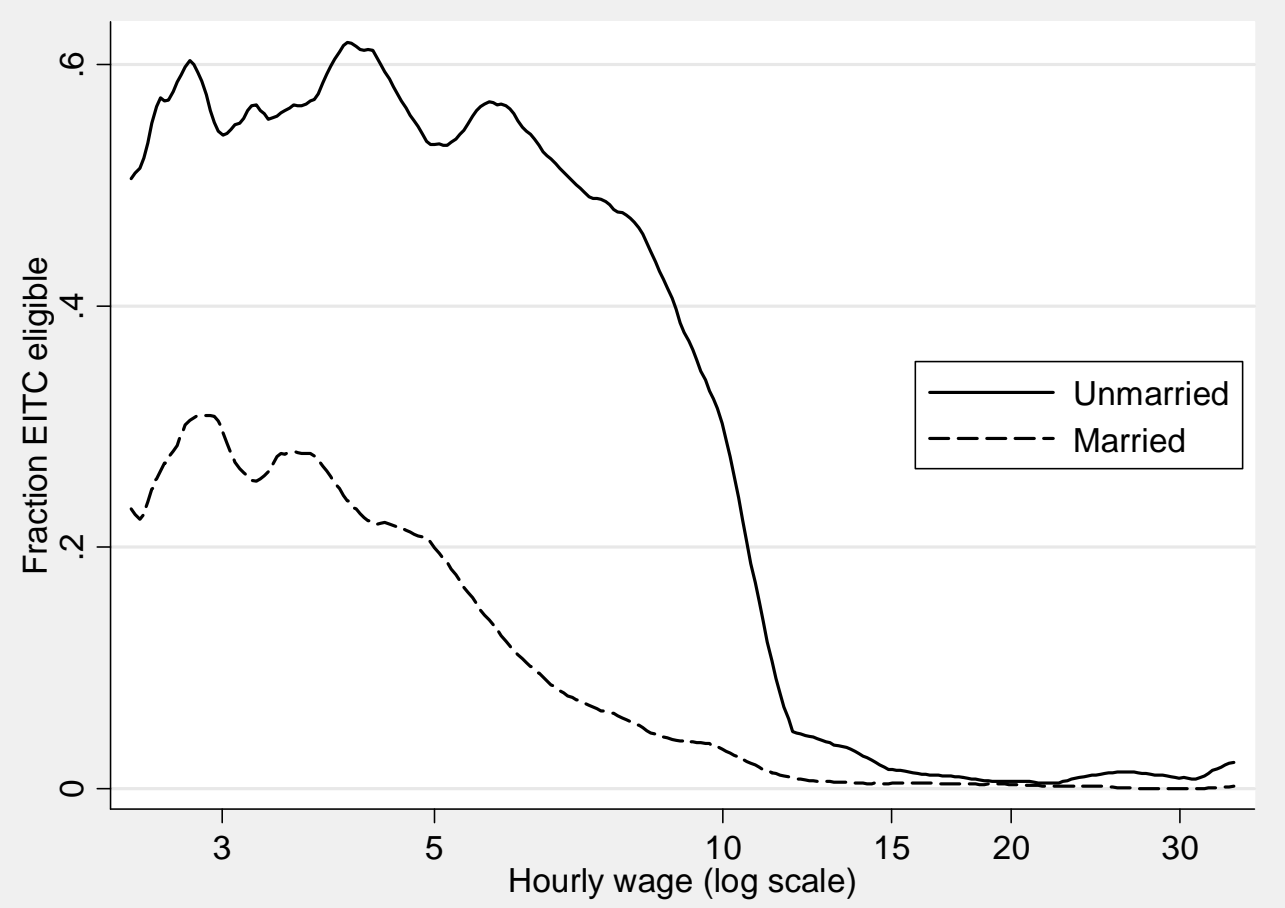

Notes: Series are estimated via local linear regressions using an Epanechnikov kernel and bandwidth $=0.05 \log$ points. 
Figure 3. Tax schedules associated with proposed EITC expansion and NIT alternative

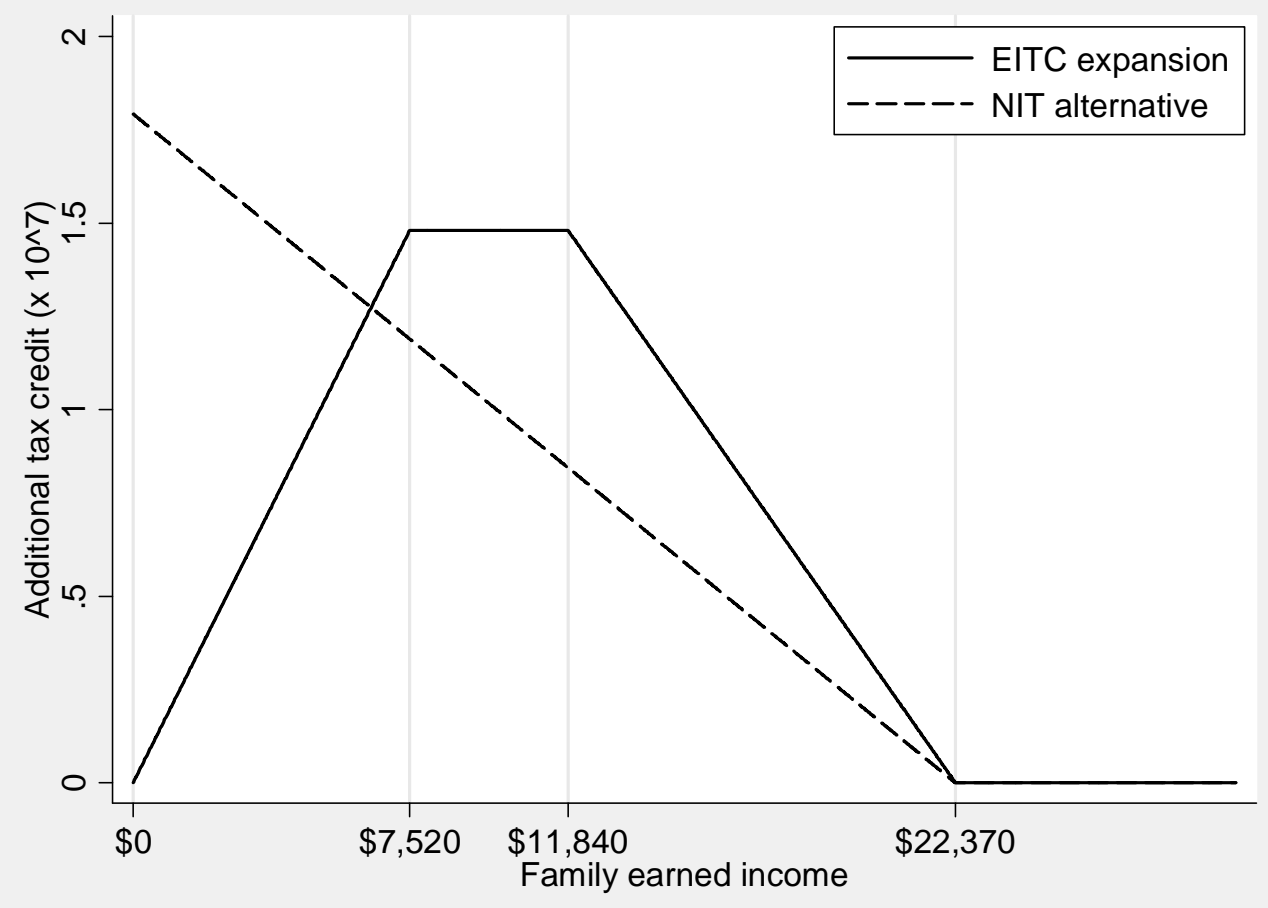

Notes: Figure indicates additional credits available (multiplied by $10^{\wedge} 7$ ) as a function of earned income for families with one child when a total of $\$ 1$ is devoted to expanding the EITC or to adding an incremental NIT. 
Figure 4. Changes in mean marginal and average tax rates associated with proposed policies, by women's marital status and hourly wage
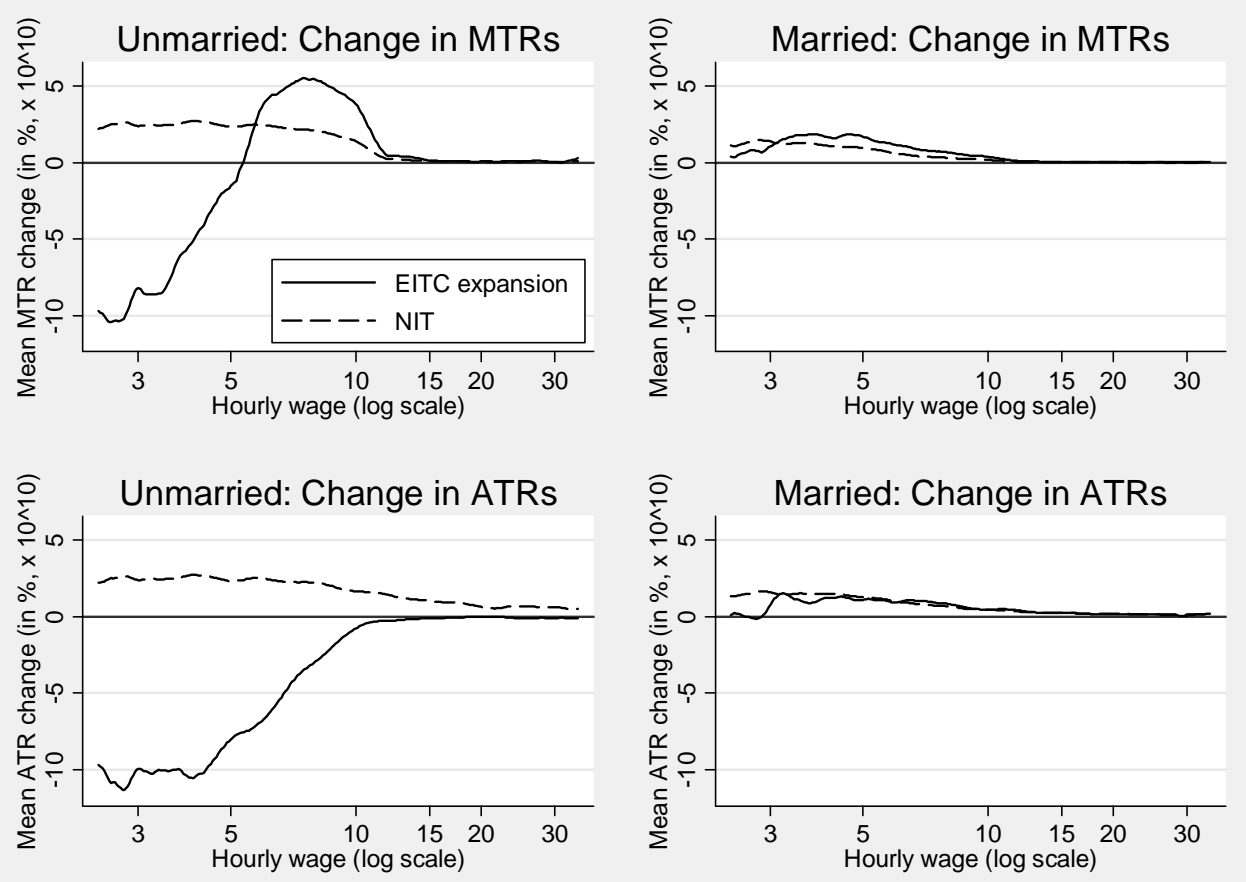

Notes: Figure indicates the mean simulated change in tax rates (in percentage points, multiplied by $10^{\wedge} 10$ ) on women's earnings when a total of $\$ 1$ is devoted to expanding the EITC or to adding an incremental NIT. Tax rates are computed using a secondary earner model, and treat husband's earnings and non-labor income as invariant to the program. Means are computed over families with children and positive female earnings, and are estimated via local linear regressions using an Epanechnikov kernel and a bandwidth of $0.05 \log$ points. 
Figure 5. Net transfers to families under EITC and NIT alternatives, by demand and supply elasticities
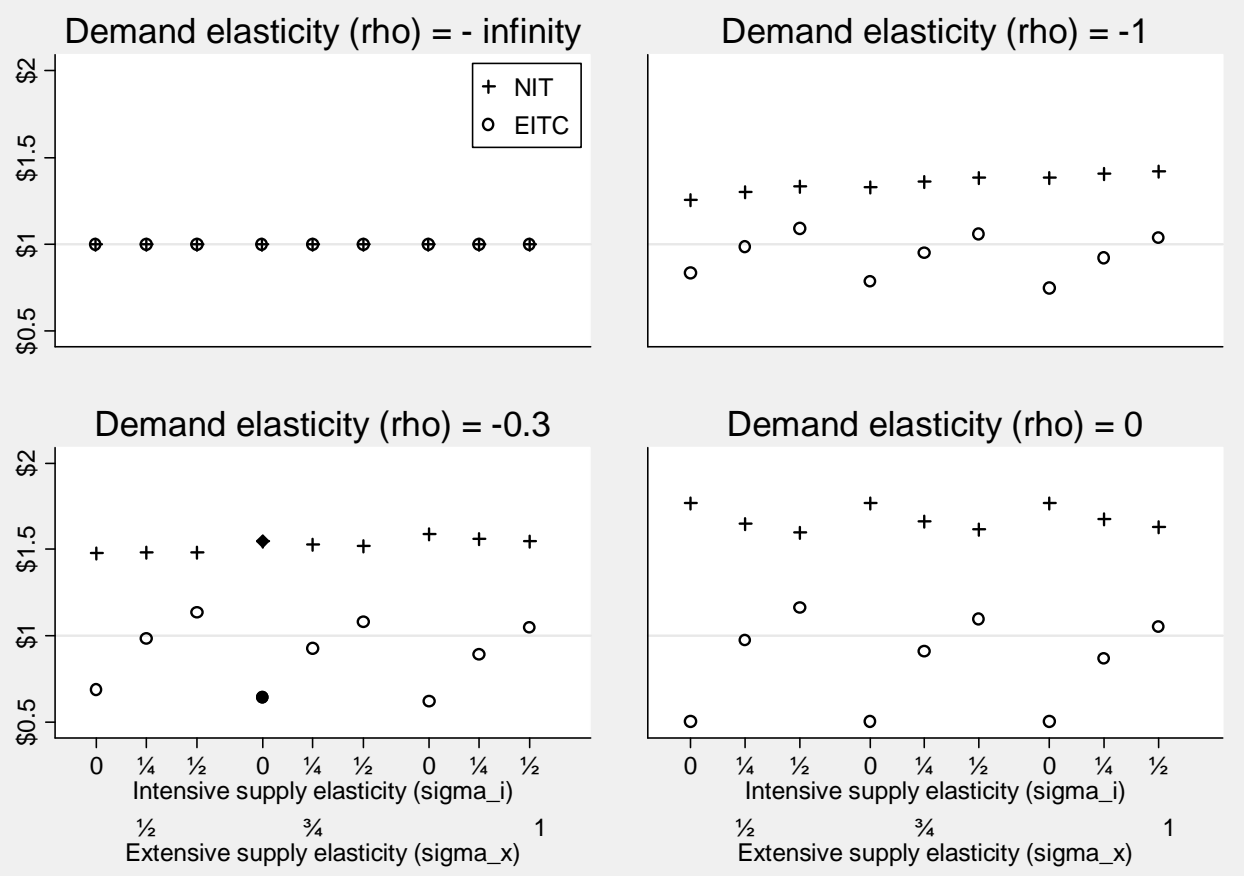

Notes: Net transfers include both tax credits paid by the government and transfers from/to employers due to increased equilibrium wages. Estimates are based on simulations of an expansion of the EITC or of a new NIT, each with total cost of $\$ 1$. Estimates corresponding to parameters used in Table 5 are highlighted (lower left panel). Horizontal lines indicate the statutory transfer (i.e., the tax credit portion). 
Figure 6. Net transfers by family type and demand elasticity under EITC and NIT alternatives
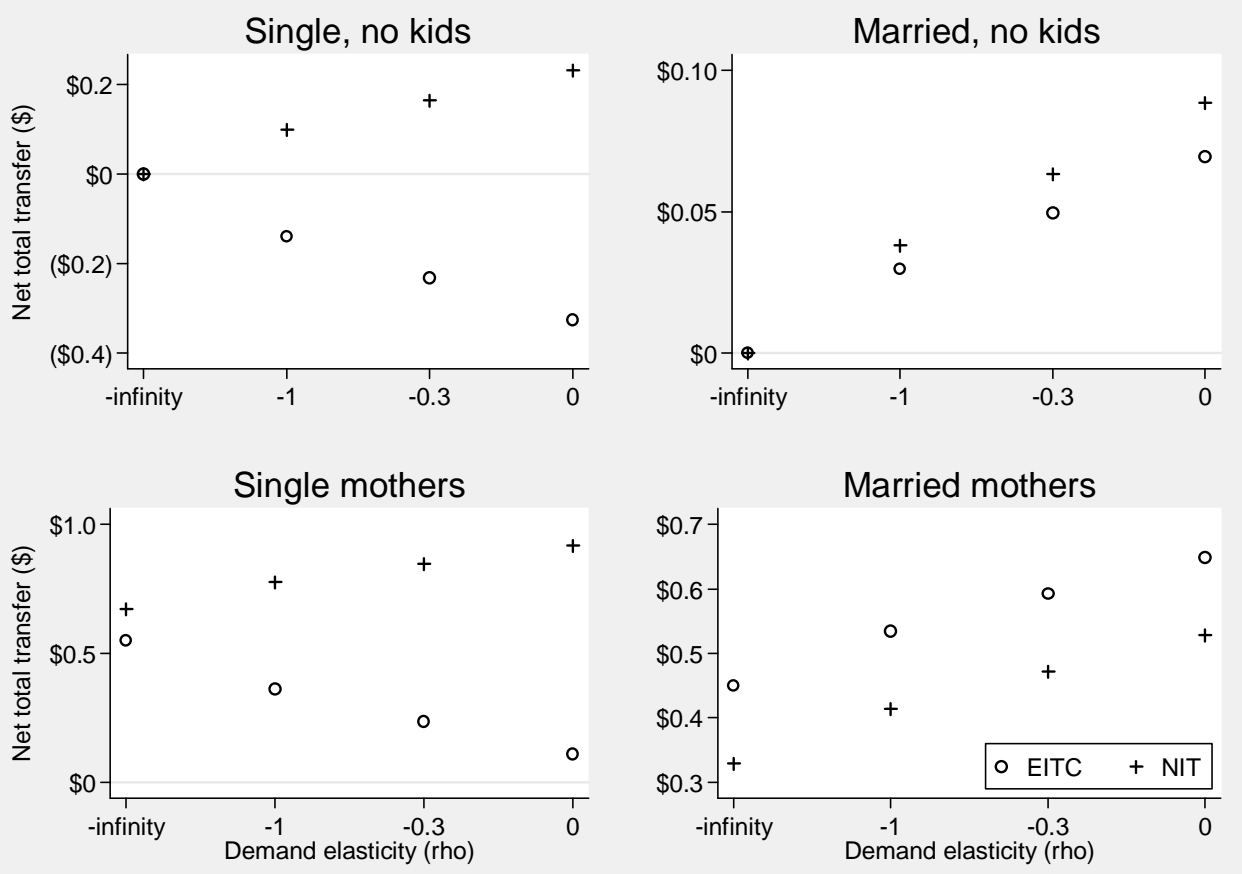

Notes: Net transfers include both tax credits paid by the government and transfers from employers due to increased equilibrium wages. Estimates are based on simulations of an expansion of the EITC or of a new NIT, each with total cost of $\$ 1$. Estimates assume $\sigma_{\mathrm{x}}=$ 0.75 and $\sigma_{\mathrm{i}}=0$. Y-axis scale varies across panels. 
Table 1. The EITC schedule

\begin{tabular}{|c|c|c|}
\hline If $y$ is & the credit is & and the marginal tax rate is \\
\hline less than or equal to 0 & 0 & 0 \\
\hline between 0 and $C / T_{1}$ & $T_{1} y$ & $-T_{1}$ \\
\hline between $C / T_{1}$ and $p$ & C & 0 \\
\hline between $p$ and $p+C / T_{2}$ & $C-\tau_{2}(y-p)$ & $T_{2}$ \\
\hline greater than $p+C / T_{2}$ & 0 & 0 \\
\hline
\end{tabular}


Table 2. Distribution of families with children across EITC segments in 1992

\begin{tabular}{|c|c|c|c|c|c|c|}
\hline & \multicolumn{3}{|c|}{ All education levels } & \multicolumn{3}{|c|}{ Less than a high school diploma } \\
\hline & \multirow{2}{*}{$\begin{array}{r}\text { Single } \\
\text { mothers }\end{array}$} & \multicolumn{2}{|c|}{ Married w/ kids } & \multirow{2}{*}{$\begin{array}{r}\text { Single } \\
\text { mothers }\end{array}$} & \multicolumn{2}{|c|}{ Married w/ kids } \\
\hline & & $\begin{array}{r}\text { Wife } \\
\text { works }\end{array}$ & $\begin{array}{r}\text { Wife } \\
\text { doesn't } \\
\text { work }\end{array}$ & & $\begin{array}{r}\text { Wife } \\
\text { works }\end{array}$ & $\begin{array}{r}\text { Wife } \\
\text { doesn't } \\
\text { work }\end{array}$ \\
\hline & $\overline{(1)}$ & (2) & (3) & $\overline{(4)}$ & (5) & $(6)$ \\
\hline $\mathrm{N}$ & 7,005 & 13,139 & 5,221 & 1,760 & 1,261 & 1,355 \\
\hline \multicolumn{7}{|c|}{$\%$ in each EITC segment, observed earnings } \\
\hline Zero earnings & $30 \%$ & $0 \%$ & $11 \%$ & $60 \%$ & $0 \%$ & $24 \%$ \\
\hline Phase-in & $19 \%$ & $2 \%$ & $7 \%$ & $19 \%$ & $8 \%$ & $13 \%$ \\
\hline Plateau & $10 \%$ & $2 \%$ & $5 \%$ & $8 \%$ & $8 \%$ & $11 \%$ \\
\hline Phase-out & $23 \%$ & $10 \%$ & $18 \%$ & $11 \%$ & $25 \%$ & $26 \%$ \\
\hline Earnings too high & $18 \%$ & $86 \%$ & $59 \%$ & $2 \%$ & $60 \%$ & $27 \%$ \\
\hline \multicolumn{7}{|c|}{ Families with positive female earnings } \\
\hline$\%$ with ATR > 0 & $0 \%$ & $26 \%$ & & $0 \%$ & $44 \%$ & \\
\hline$\%$ with ATR $<0$ & $75 \%$ & $7 \%$ & & $94 \%$ & $19 \%$ & \\
\hline
\end{tabular}

Notes: See text for sample description. Families without children and father-only families are excluded. "ATR" = "Average Tax Rate," calculated on a working woman's earnings and treating both non-labor income and husband's earnings (if any) as fixed. 
Table 3. Effects of uniform one percentage point tax increases on labor supply and wages, by elasticities of supply $(\sigma)$ and demand $(\rho)$

\begin{tabular}{|c|c|c|c|c|c|c|c|c|}
\hline & \multicolumn{2}{|c|}{$\rho=-\infty$} & \multicolumn{2}{|c|}{$\rho=-1$} & \multicolumn{2}{|c|}{$\rho=-0.3$} & \multicolumn{2}{|c|}{$\rho=0$} \\
\hline & $\begin{array}{r}\text { Change } \\
\text { in LS } \\
(1)\end{array}$ & $\begin{array}{r}\text { nange } \\
\text { in w } \\
(2)\end{array}$ & $\begin{array}{r}\text { Change } \\
\text { in LS } \\
(3)\end{array}$ & $\begin{array}{r}\begin{array}{r}\text { Change } \\
\text { in w }\end{array} \\
(4)\end{array}$ & $\begin{array}{r}\text { Change } \\
\text { in LS } \\
(5)\end{array}$ & $\begin{array}{r}\begin{array}{r}\text { Change } \\
\text { in w }\end{array} \\
(6)\end{array}$ & $\begin{array}{r}\text { Change } \\
\text { in LS } \\
(7)\end{array}$ & $\begin{array}{r}\begin{array}{r}\text { Change } \\
\text { in w }\end{array} \\
(8)\end{array}$ \\
\hline \multicolumn{9}{|c|}{ Panel A: Across-the-board 1pp increase in ATRs } \\
\hline \multicolumn{9}{|c|}{ Relatively inelastic extensive margin $\left(\sigma_{x}=0.5\right)$} \\
\hline$\sigma_{i}=0$ & $-0.50 \%$ & -- & $-0.33 \%$ & $+0.33 \%$ & $-0.19 \%$ & $+0.63 \%$ & -- & $+1.00 \%$ \\
\hline$\sigma_{i}=0.25$ & $-0.50 \%$ & -- & $-0.27 \%$ & $+0.27 \%$ & $-0.13 \%$ & $+0.43 \%$ & -- & $+0.57 \%$ \\
\hline$\sigma_{i}=0.5$ & $-0.50 \%$ & -- & $-0.22 \%$ & $+0.22 \%$ & $-0.10 \%$ & $+0.32 \%$ & -- & $+0.40 \%$ \\
\hline \multicolumn{9}{|c|}{ Central estimate of extensive margin elasticity $\left(\sigma_{x}=0.75\right)$} \\
\hline$\sigma_{i}=0$ & $-0.75 \%$ & -- & $-0.43 \%$ & $+0.43 \%$ & $-0.21 \%$ & $+0.71 \%$ & -- & $+1.00 \%$ \\
\hline$\sigma_{i}=0.25$ & $-0.75 \%$ & -- & $-0.34 \%$ & $+0.34 \%$ & $-0.15 \%$ & $+0.50 \%$ & -- & $+0.63 \%$ \\
\hline$\sigma_{i}=0.5$ & $-0.75 \%$ & -- & $-0.29 \%$ & $+0.29 \%$ & $-0.12 \%$ & $+0.39 \%$ & -- & $+0.46 \%$ \\
\hline \multicolumn{9}{|c|}{ Unit elastic extensive margin $\left(\sigma_{x}=1\right)$} \\
\hline$\sigma_{i}=0$ & $-1.00 \%$ & -- & $-0.50 \%$ & $+0.50 \%$ & $-0.23 \%$ & $+0.77 \%$ & -- & $+1.00 \%$ \\
\hline$\sigma_{i}=0.25$ & $-1.00 \%$ & -- & $-0.40 \%$ & $+0.40 \%$ & $-0.17 \%$ & $+0.56 \%$ & -- & $+0.67 \%$ \\
\hline$\sigma_{i}=0.5$ & $-1.00 \%$ & -- & $-0.33 \%$ & $+0.33 \%$ & $-0.13 \%$ & $+0.43 \%$ & -- & $+0.50 \%$ \\
\hline
\end{tabular}

Panel B: Across-the-board 1pp increase in MTRs

Relatively inelastic extensive margin $\left(\sigma_{x}=0.5\right)$

$\begin{array}{lrlrrrrrr}\sigma_{\mathrm{i}}=0 & -- & - & -- & - & -- & -- & -- & -- \\ \sigma_{\mathrm{i}}=0.25 & -0.38 \% & -- & -0.20 \% & +0.20 \% & -0.10 \% & +0.32 \% & -- & +0.43 \% \\ \sigma_{\mathrm{i}}=0.5 & -0.75 \% & -- & -0.33 \% & +0.33 \% & -0.15 \% & +0.48 \% & -- & +0.60 \%\end{array}$

Central estimate of extensive margin elasticity $\left(\sigma_{x}=0.75\right)$

$\begin{array}{lrrrrrrrr}\sigma_{\mathrm{i}}=0 & -- & - & -- & - & -- & -- & -- & -- \\ \sigma_{\mathrm{i}}=0.25 & -0.44 \% & -- & -0.20 \% & +0.20 \% & -0.09 \% & +0.29 \% & -- & +0.37 \% \\ \sigma_{\mathrm{i}}=0.5 & -0.88 \% & -- & -0.33 \% & +0.33 \% & -0.14 \% & +0.45 \% & -- & +0.54 \%\end{array}$

Unit elastic extensive margin $\left(\sigma_{x}=1\right)$

\begin{tabular}{lrlrrrrrr}
$\sigma_{i}=0$ & -- & -- & -- & - & -- & -- & -- & -- \\
$\sigma_{i}=0.25$ & $-0.50 \%$ & -- & $-0.20 \%$ & $+0.20 \%$ & $-0.08 \%$ & $+0.28 \%$ & -- & $+0.33 \%$ \\
$\sigma_{i}=0.5$ & $-1.00 \%$ & -- & $-0.33 \%$ & $+0.33 \%$ & $-0.13 \%$ & $+0.43 \%$ & -- & $+0.50 \%$ \\
\hline
\end{tabular}

Notes: Table shows the effect of a 1 percentage point across-the-board increase in the ATR (panel A) or MTR (panel B). Change in labor supply combines participation and hours responses, as in equation (13). Change in wage refers to the pre-tax hourly wage. $\sigma_{x}$ and $\sigma_{i}$ are the elasticity of labor supply on the extensive and intensive margins, respectively. $\rho$ is the elasticity of labor demand. 
Table 4. Impacts of EITC and NIT expansions without incidence effects (perfectly elastic demand)

\begin{tabular}{|c|c|c|c|c|c|c|c|c|c|c|}
\hline & \multirow{3}{*}{\multicolumn{2}{|c|}{$\begin{array}{r}\text { All } \\
\text { women } \\
(1)\end{array}$}} & \multicolumn{4}{|c|}{ Single women } & \multicolumn{4}{|c|}{ Married women } \\
\hline & & & \multicolumn{2}{|c|}{ w/ kids } & \multicolumn{2}{|c|}{ no kids } & \multicolumn{2}{|r|}{ w/ kids } & \multicolumn{2}{|c|}{ no kids } \\
\hline & & & & $(2)$ & & (3) & & (4) & & (5) \\
\hline \multicolumn{11}{|l|}{ Panel A: EITC expansion } \\
\hline Intended tax transfer & $\$$ & 1.00 & $\$$ & 0.55 & $\$$ & - & $\$$ & 0.45 & $\$$ & - \\
\hline To families with earned income & $\$$ & 1.00 & $\$$ & 0.55 & $\$$ & - & $\$$ & 0.45 & $\$$ & - \\
\hline Change in labor supply (in \$ of earnings) & $\$$ & 0.39 & $\$$ & 0.61 & $\$$ & - & $\$$ & $(0.22)$ & $\$$ & - \\
\hline Change in after-tax income & $\$$ & 1.39 & $\$$ & 1.16 & $\$$ & - & $\$$ & 0.23 & $\$$ & - \\
\hline \multicolumn{11}{|l|}{ Panel B: NIT expansion } \\
\hline Intended tax transfer & $\$$ & 1.00 & $\$$ & 0.67 & $\$$ & - & $\$$ & 0.33 & $\$$ & - \\
\hline To families with earned income & $\$$ & 0.56 & $\$$ & 0.33 & $\$$ & - & $\$$ & 0.23 & $\$$ & - \\
\hline Change in labor supply (in \$ of earnings) & $\$$ & $(0.62)$ & $\$$ & $(0.38)$ & $\$$ & - & $\$$ & $(0.24)$ & $\$$ & - \\
\hline Change in after-tax income & $\$$ & 0.38 & $\$$ & 0.29 & $\$$ & - & $\$$ & 0.09 & $\$$ & - \\
\hline
\end{tabular}

Notes: Simulations are of an EITC or NIT expansion targeted at families with children, with total expenditure of $\$ 1$ (in the absence of labor supply or wage effects). Simulation assumes $\sigma_{x}=0.75, \sigma_{i}=0$, $\rho=-\infty$. Parentheses indicate negative numbers. 
Table 5. Impacts of EITC and NIT expansions with encidence effects (demand elasticity $=\mathbf{- 0 . 3 \text { ) }}$

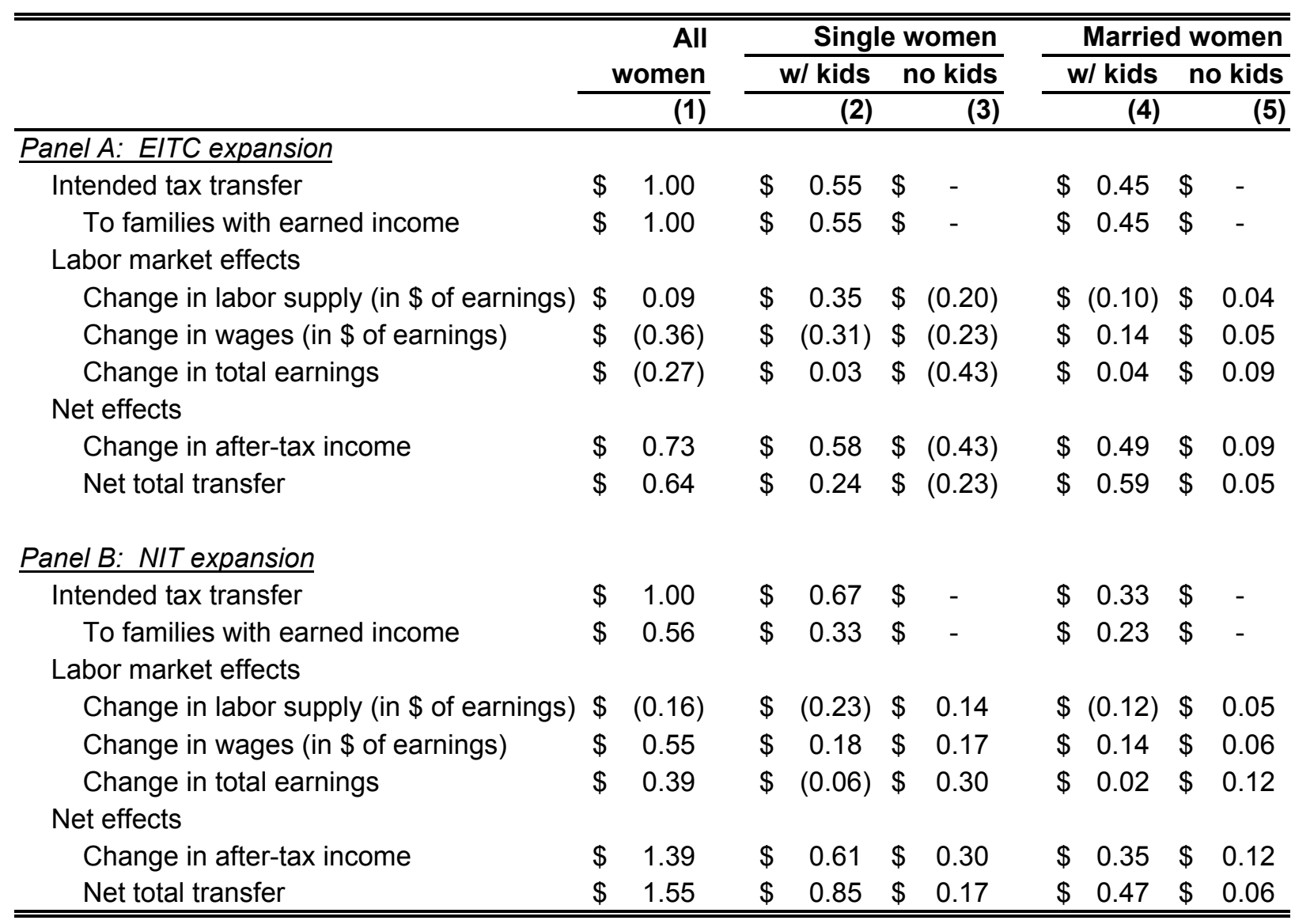

Notes: Simulations are of an EITC or NIT expansion targeted at families with children, with total expenditure of $\$ 1$ (in the absence of labor supply or wage effects). Elasticities are $\sigma_{x}=0.75, \sigma_{i}=0, \rho=-0.3$. Parentheses indicate negative numbers. 
Table 6. Incidence effects with intensive margin responses (intensive labor supply elasticity = 0.25)

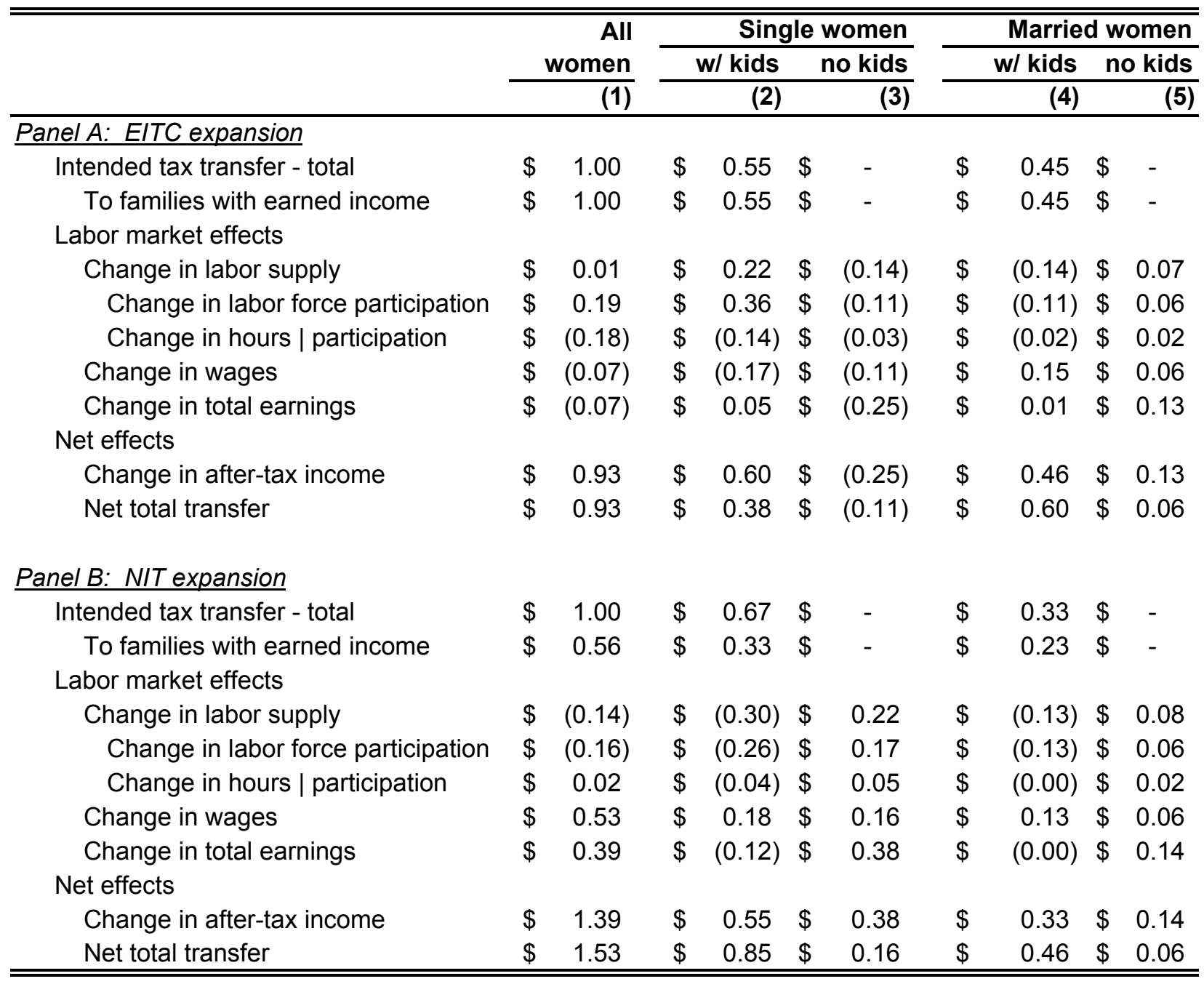

Notes: Simulations are of an EITC or NIT expansion targeted at families with children, with total expenditure of $\$ 1$ (in the absence of labor supply or wage effects). Elasticities are $\sigma_{x}=0.75, \sigma_{i}=0.25, \rho=-$ 0.3. Parentheses indicate negative numbers. 
Table 7. Sensitivity of effects to labor market definitions

\begin{tabular}{|c|c|c|c|c|c|}
\hline & \multicolumn{3}{|c|}{ Net total transfer } & \multicolumn{2}{|c|}{ Change in after-tax income } \\
\hline & All & romen & $\begin{array}{r}\text { Single } \\
\text { mothers }\end{array}$ & All women & $\begin{array}{r}\text { Single } \\
\text { mothers }\end{array}$ \\
\hline & & (1) & $(2)$ & (3) & (4) \\
\hline \multicolumn{6}{|l|}{ Panel A. EITC } \\
\hline \multicolumn{6}{|c|}{ Markets segmented by marital status } \\
\hline Education-experience & $\$$ & 0.64 & 0.24 & 0.73 & 0.58 \\
\hline Geography-education & $\$$ & 0.60 & 0.29 & 0.68 & 0.73 \\
\hline Wage (continuous) & $\$$ & 0.78 & 0.34 & 0.84 & 0.59 \\
\hline \multicolumn{6}{|l|}{ Markets not segmented } \\
\hline Education-experience & $\$$ & 0.64 & 0.46 & 0.73 & 0.99 \\
\hline Geography-education & $\$$ & 0.57 & 0.48 & 0.63 & 1.08 \\
\hline Wage (continuous) & $\$$ & 0.78 & 0.50 & 0.84 & 0.88 \\
\hline \multicolumn{6}{|c|}{ Panel B. NIT } \\
\hline \multicolumn{6}{|c|}{ Markets segmented by marital status } \\
\hline Education-experience & $\$$ & 1.55 & 0.85 & 1.39 & 0.61 \\
\hline Geography-education & $\$$ & 1.57 & 0.82 & 1.42 & 0.56 \\
\hline Wage (continuous) & $\$$ & 1.52 & 0.82 & 1.37 & 0.57 \\
\hline \multicolumn{6}{|l|}{ Markets not segmented } \\
\hline Education-experience & $\$$ & 1.55 & 0.78 & 1.39 & 0.49 \\
\hline Geography-education & $\$$ & 1.58 & 0.76 & 1.44 & 0.44 \\
\hline Wage (continuous) & $\$$ & 1.52 & 0.76 & 1.37 & 0.46 \\
\hline
\end{tabular}

Notes: Each row corresponds to a distinct definition of the relevant labor market. Each simulation uses baseline elasticity parameters: $\sigma_{x}=0.75, \sigma_{i}=0, \rho=-0.3$. 
Table 8. Distribution of net transfers with baseline parameters

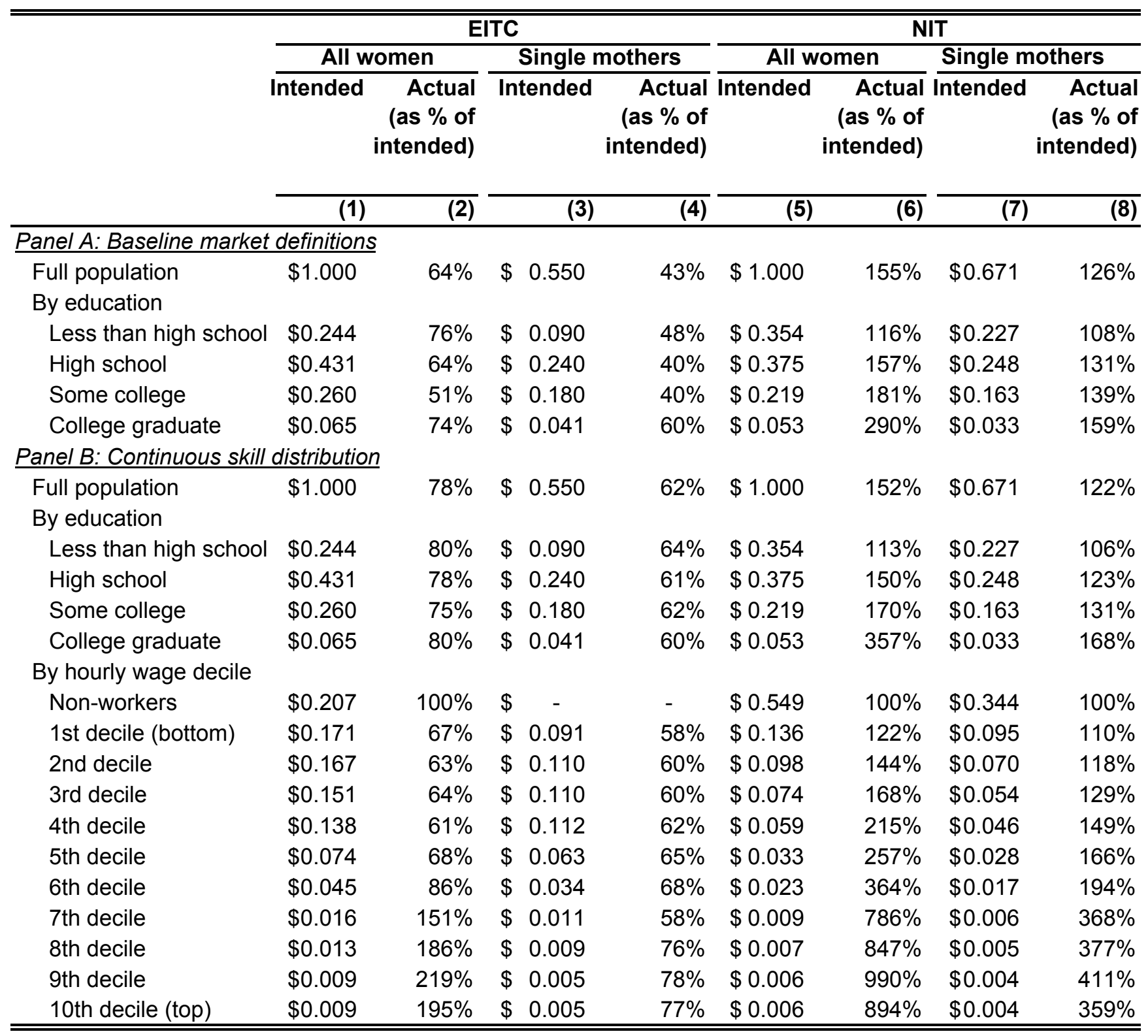

Notes: Simulations use baseline elasticity parameters: $\sigma_{x}=0.75, \sigma_{i}=0, \rho=-0.3$. 